\title{
Modifying the ADM1 Model to Predict the Operation of an Anaerobic Digester Co-digesting Municipal Sludge with Bakery Waste
}

\author{
Morris E. Demitry ${ }^{1}$, Jianming Zhong ${ }^{1}$, Conly Hansen ${ }^{2} \&$ Michael McFarland ${ }^{1}$ \\ ${ }^{1}$ Department of Civil and Environmental Engineering, Utah State University, USA \\ ${ }^{2}$ NDFS, Utah State University, USA \\ Correspondence: Morris E. Demitry, Department of Civil and Environmental Engineering, Utah State University, \\ USA. E-mail: morris.d@aggiemail.usu.edu
}

Received: June 9, 2015 Accepted: September 16, 2015 Online Published: September 28, 2015

doi:10.5539/ep.v4n4p38 URL: http://dx.doi.org/10.5539/ep.v4n4p38

\begin{abstract}
Anaerobic Digestion Model Number1 (ADM1) was modified in order to predict accurately the impact of co-digesting bakery waste (BW) with municipal sludge (MS). BW is an industrial waste $(300,000$ gallons per day in USA) that contains a high concentration of organic matter (carbohydrates, low lipids and non-detected proteins). BW is an easily biodegradable substrate for creating a favorable microorganism growth environment, which enhances the biogas production needed for wastewater facilities. The modified ADM1 successfully predicted changes in $\mathrm{pH}$, volatile fatty acids (VFA), propionic acid and methane gas production. The ADM1 outputs were compared to experimental batch reactor results of actual BW addition percentages in order to validate the model. Stability of the digestion process was achieved until the ratio range of $37-40 \%$ BW: $60-63 \%$ MS, and the digestion processes were inhibited at higher ratios of BW. This research provides an alternative to BW management through utilizing the BW to enhance methane production.
\end{abstract}

Keywords: ADM1 model, bakery waste, biogas, co-digestion, municipal sludge, stability

\section{Introduction}

The anaerobic digestion process is one of the oldest biological process technologies utilized by mankind. The process was first used for food and beverages production, and then developed in the last few decades for wastewater sludge stabilization.

One of the main advantages of the anaerobic process is the high organic loading and low sludge production combined with the amount of energy produced (Turovskii and Mathai 2006). The energy produced from the process is sufficient that it could potentially replace fossil fuel sources as an alternative renewable energy option. The anaerobic digestion process is complicated since it involves many chemical, biological, and physical interactions that must be balanced within the ecosystem.

Stability of anaerobic digestion is an important challenge for scientists and engineers. Changes in the digester environment may affect the stability of the process and the consequences of failure are substantial in terms of regulatory compliance, environmental degradation, and economic impact. Failure of the digester will negatively affect sludge treatment; also, the restart of the digestion process in case of failure is prohibitively expensive(Bitton 2011).

Mathematical modeling reduces the failure risks associated with the anaerobic process; computer models can simulate the process and predict outcomes, thereby helping to reduce the risk of imbalance in the digestion process (Burton 2004; Gary AMY 2008). In this research, the Anaerobic Digestion Model Number1 (ADM1) has been used to simulate the situation of co-digestion bakery waste (BW) with municipal sludge (MS).

There are reports on anaerobic co-digestion of different kinds of industrial waste with sludge (Callaghan et al. 1999; Fountoulakis et al. 2010; Silvestre et al. 2011; Ye Chen 2007; Zhu et al. 2008). However, a specific lack of knowledge exists about the co-digestion of BW (cookies, cakes, and pies) with MS and its potential impact on anaerobic process stability. Furthermore, using the ADM1 model to study and predict the impact of BW mixed with MS for anaerobic digestion, and determining the failure point of the anaerobic digestion process has not been studied or reported. 


\section{Background}

\subsection{Stability of the Anaerobic Digestion}

While anaerobic digestion is an attractive method for pollution control and energy recovery (Burton 2004), many factors may affect the balance between microorganisms or inhibit them in the anaerobic digester; for example, changes in temperature, retention time (related to loading), $\mathrm{pH}$ and toxic materials (Bitton 2011). Inhibition of the available microorganisms will affect the stability of the digester and may prevent it from being widely commercialized (Dupla et al. 2004) for some substrates. Failure to maintain the balance between the acid formers and the methane formers is the main reason for digester instability (Demirel 2002).

Researches have been done to try to enhance methane gas production during co-digestion of food waste by combining it with other organic matter (Fang et al. 2011; Jiang et al. 2013; Kabouris et al. 2009; Kabouris 2008; L. Martín-Gonzáleza 2010; Long et al. 2012). Wastes from food processers are high in organic matter and thus resulting in high methane gas production, but this same organic material can also inhibit anaerobic microorganisms (Chen et al. 2008). For example, co-digestion of certain food wastes such as meat waste will increase the accumulation of ammonia and volatile fatty acids (VFA); these two substances are potent inhibitors to anaerobic microorganisms in specific concentrations (Kayhanian 1999).

Monitoring the digester parameters such as $\mathrm{pH}$, VFA (acetic, propionic, valeric and butyric), and hydrogen is important; those parameters are used as an early indicators to discover any undesirable inhibition in the microbial community, and to avoid instability of the digester. Accumulation of $2000 \mathrm{mg} / \mathrm{L}$ of VFA inside the digester and above $300 \mathrm{mg} / \mathrm{L}$ of propionic acid will result in chronic inhibition of the necessary microorganism environment (Wang et al. 2009). Monitoring daily flow of biogas (Q) and the percentage of methane gas $\left(\mathrm{CH}_{4}\right)$ are important to ensure a healthy environment for microorganisms in an anaerobic digester. These parameters can be used to evaluate the efficiency of a co-digestion process for enhancing biogas from a wastewater treatment facilities' digester. (Bitton 2011; Burton 2004; Demirel 2002; Henze 2008; Jiang et al. 2013; McCarty 1973; Turovskiĭ and Mathai 2006).

\subsection{Bakery Waste}

The bakery industry is one of the major food industries throughout the world. Bakery products are categorized as bread, bread rolls and pastry products including cakes, donuts, biscuits, and pies. There are almost 7,000 bakery operations in the USA consuming approximately 300,000 gal of water per day and more than half of it is discharged as wastewater (Lawrence K. Wang 2006).

BW is rich in carbohydrates and low in lipids and proteins ( $80 \%$ carbohydrates, $20 \%$ lipids and non-detected proteins). The $\mathrm{BW}$ is generated from cleaning operations (equipment and floor); the waste is collected into touts (300 gal per tout) and transported to landfill application (based on information collected from CSM Bakery Products, Ogden, UT). The digesting of BW with MS will minimize the need to landfill BW products and will enhance the biogas production inside the wastewater facilities.

\subsection{Model Description}

The ADM1 model was established by the International Water Association (IWA) Task Group for mathematical modeling of the anaerobic digestion process (Batstone and Keller 2003). ADM1 is a mechanistic model that has open structure, common nomenclature integrating biokinetics with association-dissociation, gas-liquid transfer, and cellular processes involving hydrolysis, acidogenesis, acetogenesis, and methanogenesis. The model uses a large number of constants and coefficients in order to describe the physical-chemical reactions.

Organic matter is characterized according to its Chemical Oxygen Demand (COD) in the ADM1 model. The model applies some variables to describe the behavior of soluble and particulate components. The COD entering the digester is defined as biodegradable and non-biodegradable organic matter. Usually it is a challenge to estimate the percentage of these parameters since most of the time sludge COD is not reported (Parker 2005). However, the IWA group does not provide clear information on how the fraction of carbohydrates, proteins and lipids can be divided for MS (Shang et al. 2005). Sludge composition based on COD, may contain 35\% inert, 20\% proteins, $20 \%$ carbohydrates, and $25 \%$ lipids. Accordingly, the COD in this study was divided into the ratios shown in Figure 1. 


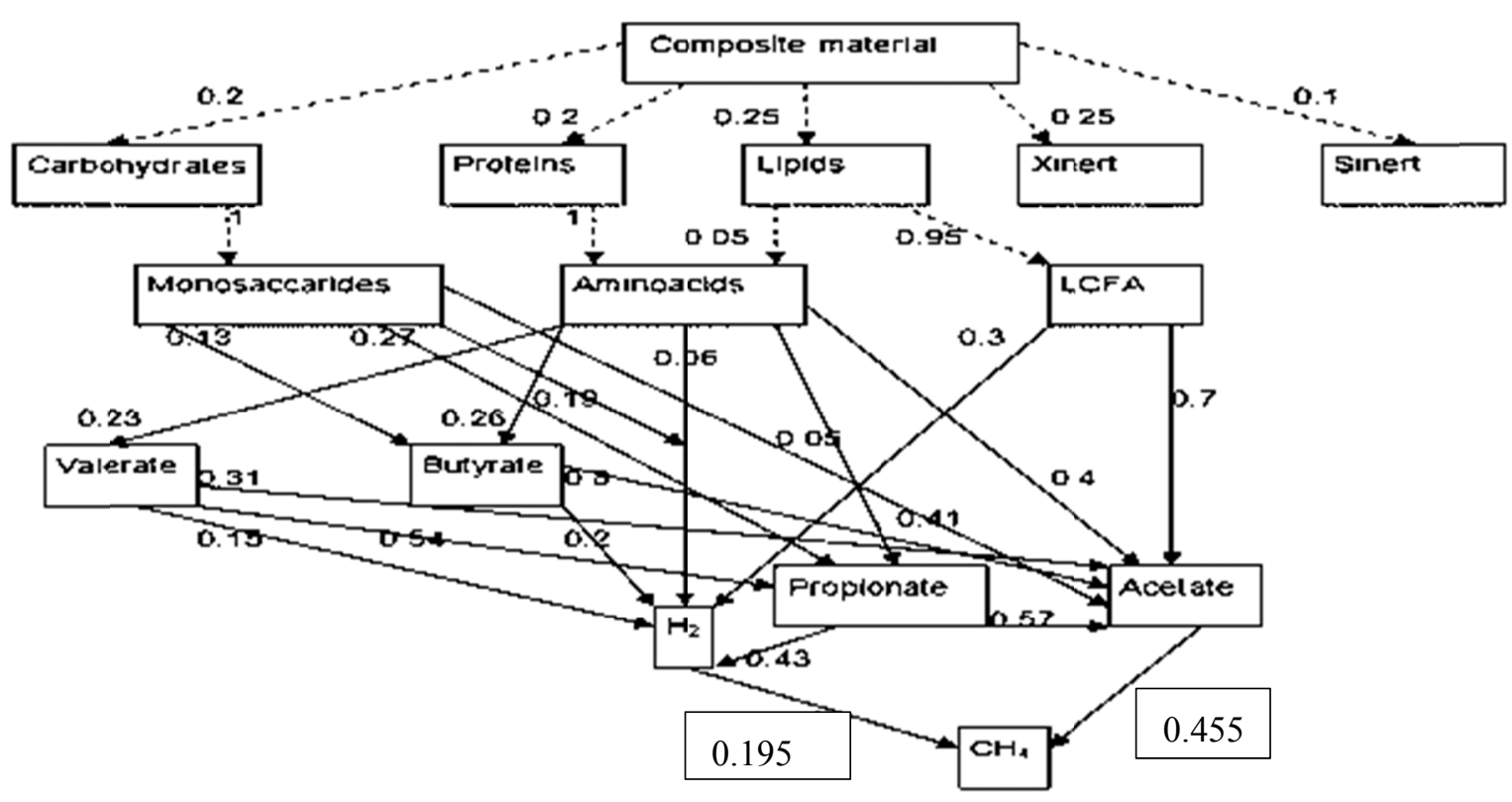

Figure 1. The COD flux for sewage sludge (Batstone et al. 2002)

In Figure 1, boxes represent products, numerical values represent COD fraction, and arrows represent the direction of mass balance. MS consist of 0.65 as biodegradable organic matter like carbohydrates, proteins and lipids, while 0.35 of the MS is non-biodegradable organic matter. The non-biodegradable MS includes both particulate (Xinert), and soluble (Sinert) materials. Bacterial reactions degrade the complex organic to simple organic matter, then to an intermediate products like volatile fatty acids (Acetate, Propionate, Butyrate, and Valerate). Finally, methanogensis archaea converts acetate and hydrogen to methane gas (Batstone et al. 2002).

\section{Objectives}

The objectives of this research can be subdivided into the following categories:

3.1 Modify and validate an existing mathematical model (ADM1) to be used for BW co-digestion purposes.

3.2 Use the modified ADM1 model to simulate and study the changes in the digester's behavior, and predict the increase of methane gas due to the injection of BW.

3.3 Use the modified model to determine the imbalance point of the digester due to BW mixed with MS.

3.4 Draw conclusions for further research and use of both the modified model and the process of utilizing BW itself.

\section{Materials and Methods}

The code of the ADM1 was written using R programing software to describe all the processes and the mathematical dynamic equations that used in ADM1 model.

The ADM1 model using R programing was applied to a full-scale anaerobic digester at Central Weber Sewer Improvement District (CWSID), Ogden, Utah. Sludge samples for measurements of $\mathrm{pH}, \mathrm{COD}$, alkalinity, Total Kjeldahl nitrogen (TKN), ammonia $\mathrm{NH}_{3}$, total solids (TS), volatile solids (VS), and VFA were collected from the anaerobic digester at CWSID; the results are displayed in Table 1. The full-scale digester was monitored for 4 months (June - October 2014) .The standard methods for the examination of wastewater were used for the analysis of each parameter (APHA 2005).

Gas samples were also collected from the full-scale anaerobic digester at CWSID in order to measure the methane gas, carbon dioxide gas, and hydrogen gas content of the biogas by volume. The volume of the digester at CWSID was $5230 \mathrm{~m}^{3}$ operated under mesophilic temperature $\left(95-98^{\circ} \mathrm{F}\right)$ with a retention time of 20 days. The sludge at CWSD was $75 \%$ secondary sludge (waste activated sludge) and $25 \%$ primary sludge.

BW samples were collected from CSM Bakery Products, Ogden, UT for 4 months (August- December 2014); the characteristics of the BW are displayed in Table 1. 
Co-digesting of BW with MS was done in pilot scale batch-reactors at the Utah Water Research Laboratory (UWRL), Logan, Utah. Ratios of mixing BW with MS based on total COD were done at $10 \%, 20 \%, 30 \%, 35 \%$, $36 \%, 37 \%, 40 \%, 42 \%, 44 \% \mathrm{BW}$. BW was added to the MS in the batch reactor without being diluted; twelve 500 $\mathrm{mL}$ batch reactors were used. For each ratio of BW, the batch reactors experiment was triplicated in three identical reactors. The reactors were well-mixed using automatic shakers (Lab Line Instrument Company, Melrose Park, Illinois); the speed of the shakers were scaled at number 2. The operating temperature of the reactors was $97^{\circ} \mathrm{F}$. Each experiment was conducted for 30 days. The BW contained $80 \%$ of the COD as carbohydrate and $20 \%$ as lipids; proteins were not detected. The ADM1 was modified to better predict performance while co-digesting BW with MS; the coefficient parameters of the model were modified based on the chemical composition of MS and BW as shown in Table 1. The model was validated and tested using the results from the pilot scale (batch reactors) experiments in each stage.

\section{Results and Discussion}

\subsection{Stage 1: Modeling of Full-Scale Digester}

The ADM1 model was run to predict the parameters $\mathrm{pH}$, VFA, propionic acid, biogas $\mathrm{Q}(\mathrm{L} / \mathrm{d})$, methane gas $(\mathrm{L} / \mathrm{d})$ and hydrogen gas. The first run of the model assumed that the COD is divided to $20 \%$ carbohydrates, $20 \%$ proteins and $25 \%$ lipids, while $35 \%$ of the COD was assumed as inert (non-biodegradable) as shown in Figure 1. For the initial run, values for MS kinetic parameters recommended by Batstone and Keller, 2003 were used in this model.

The model outputs were compared to the observed results from the full-scale digester at CWSID.

Figures $2-5$ show the comparison between predicted and observed parameters for the MS before adding BW to the digester.

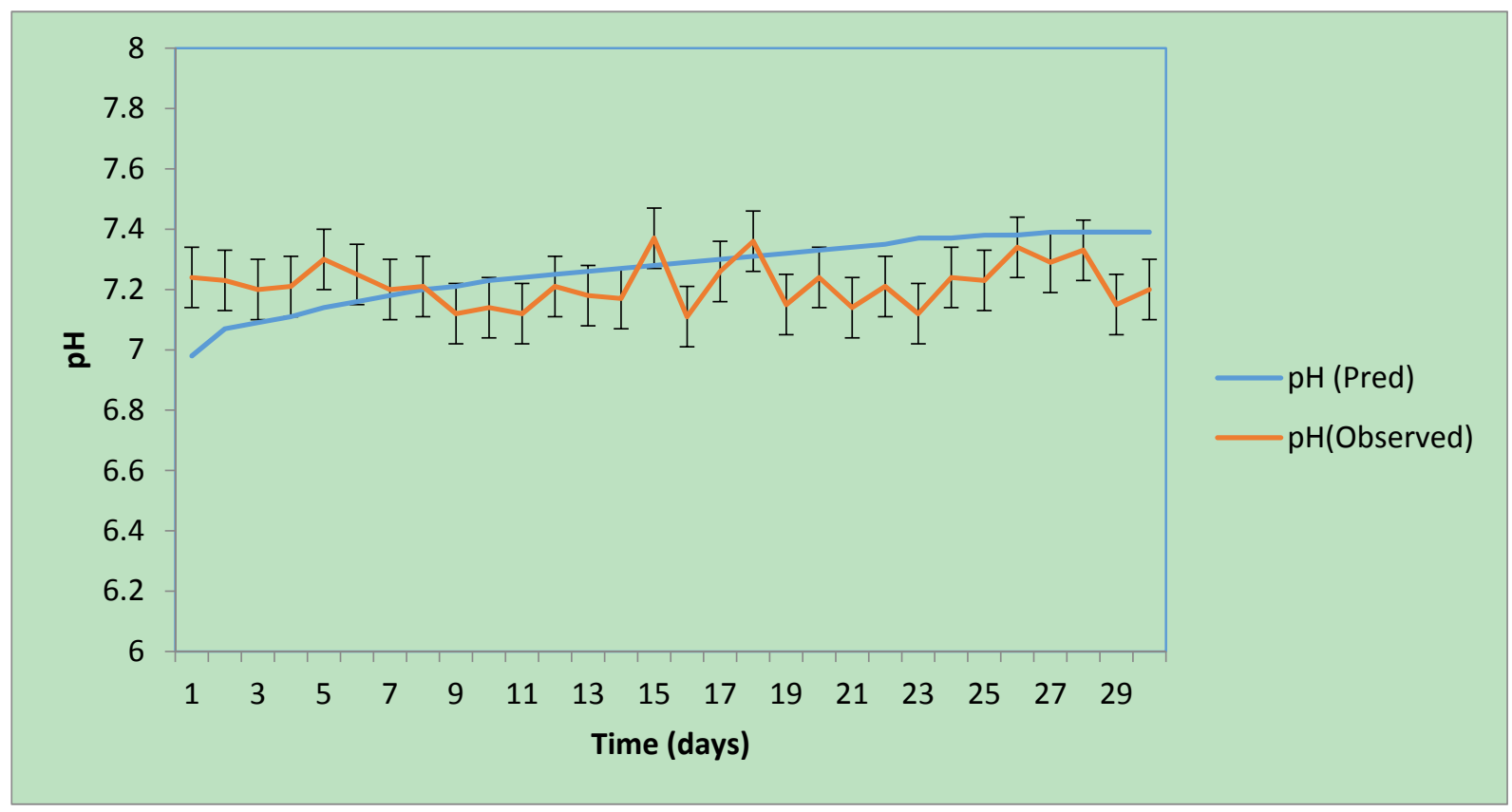

Figure 2. Comparison between predicted and observed $\mathrm{pH}$ (Error bars $=$ Standard Deviation) 


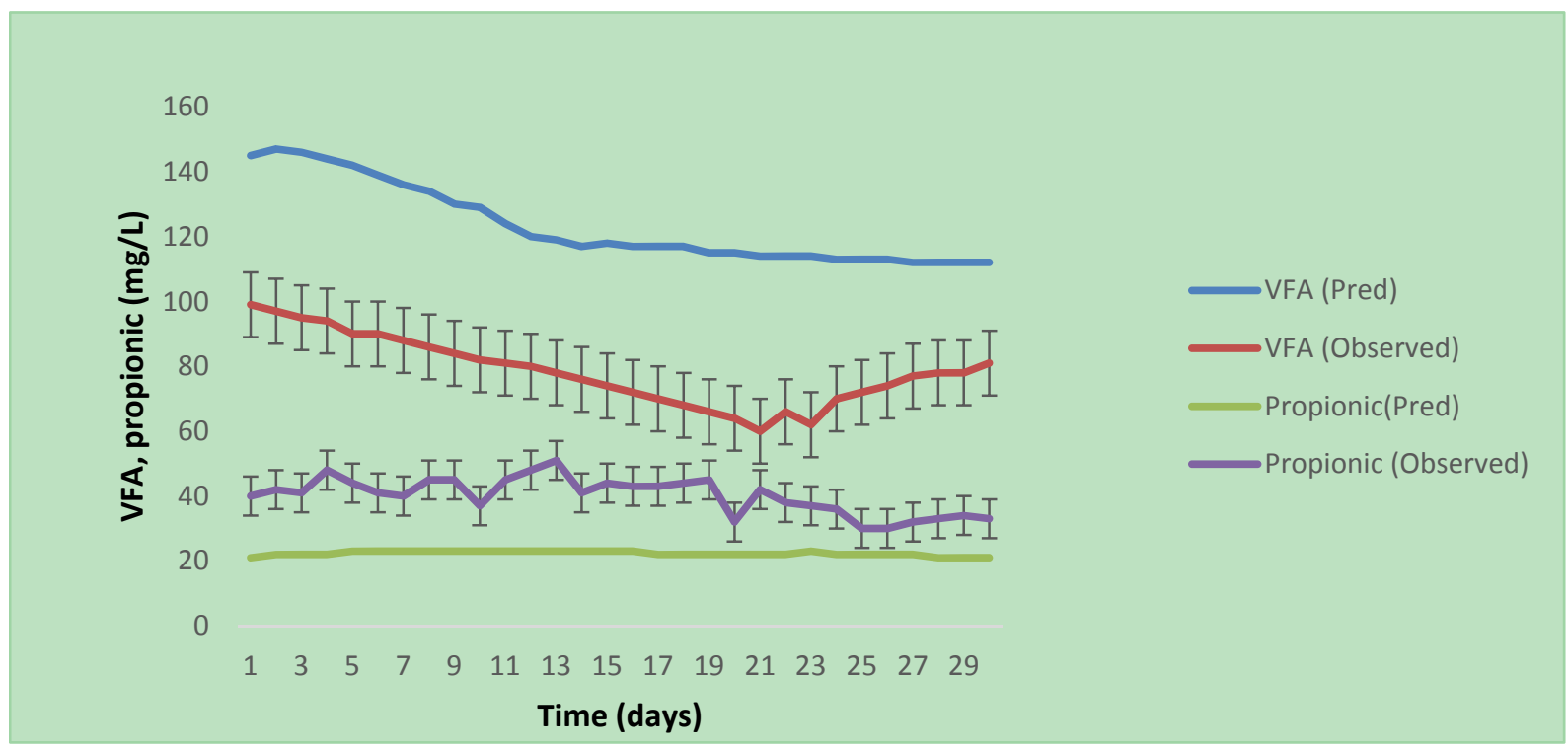

Figure 3. Comparison between predicted and observed VFA and propionic acid (Error Bars $=$ Standard Deviation)

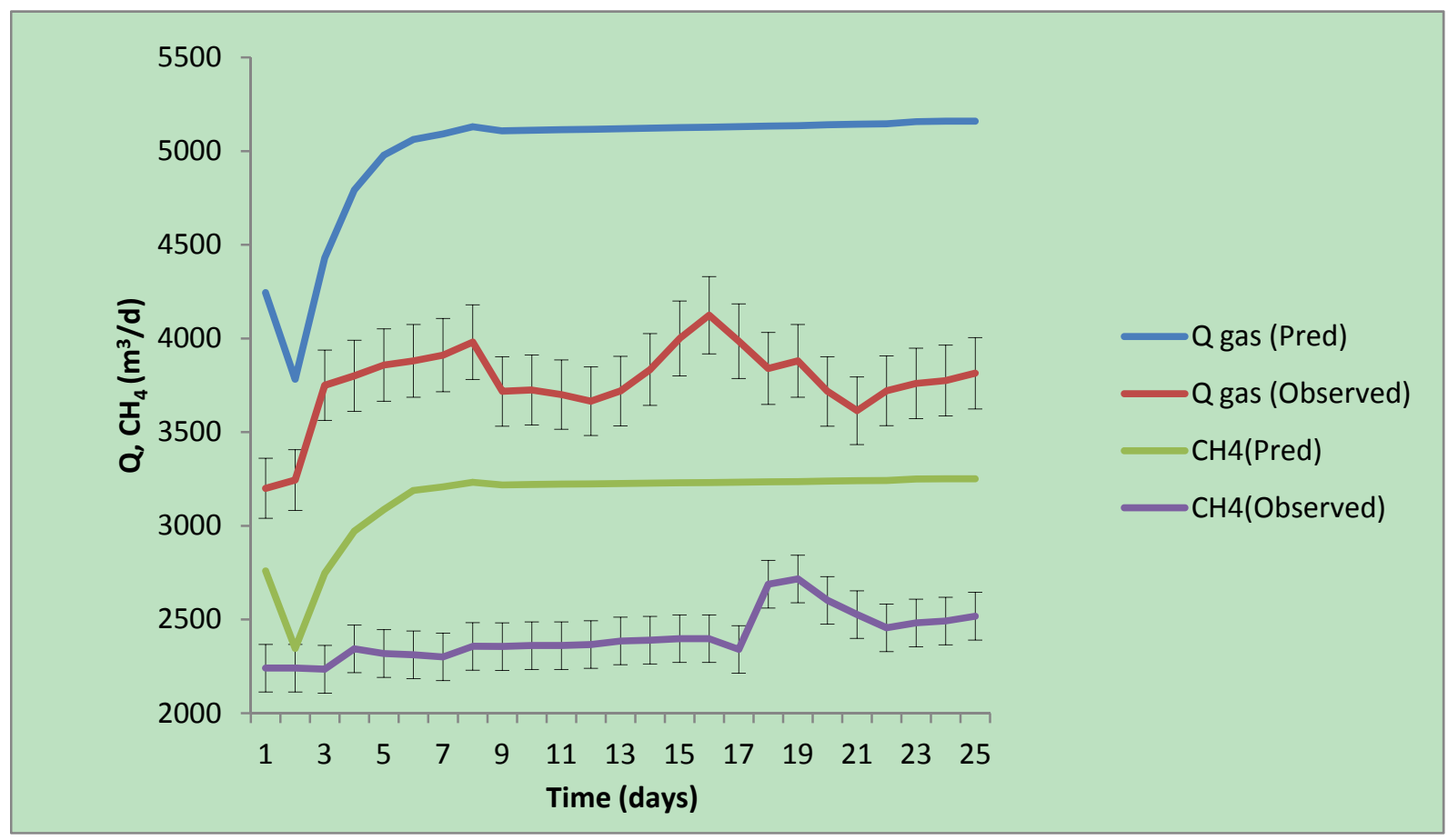

Figure 4. Comparison between predicted and observed $\mathrm{Q}$ and $\mathrm{CH}_{4}(\mathrm{~L} / \mathrm{d})($ Error Bars $=$ Standard Deviation $)$ 


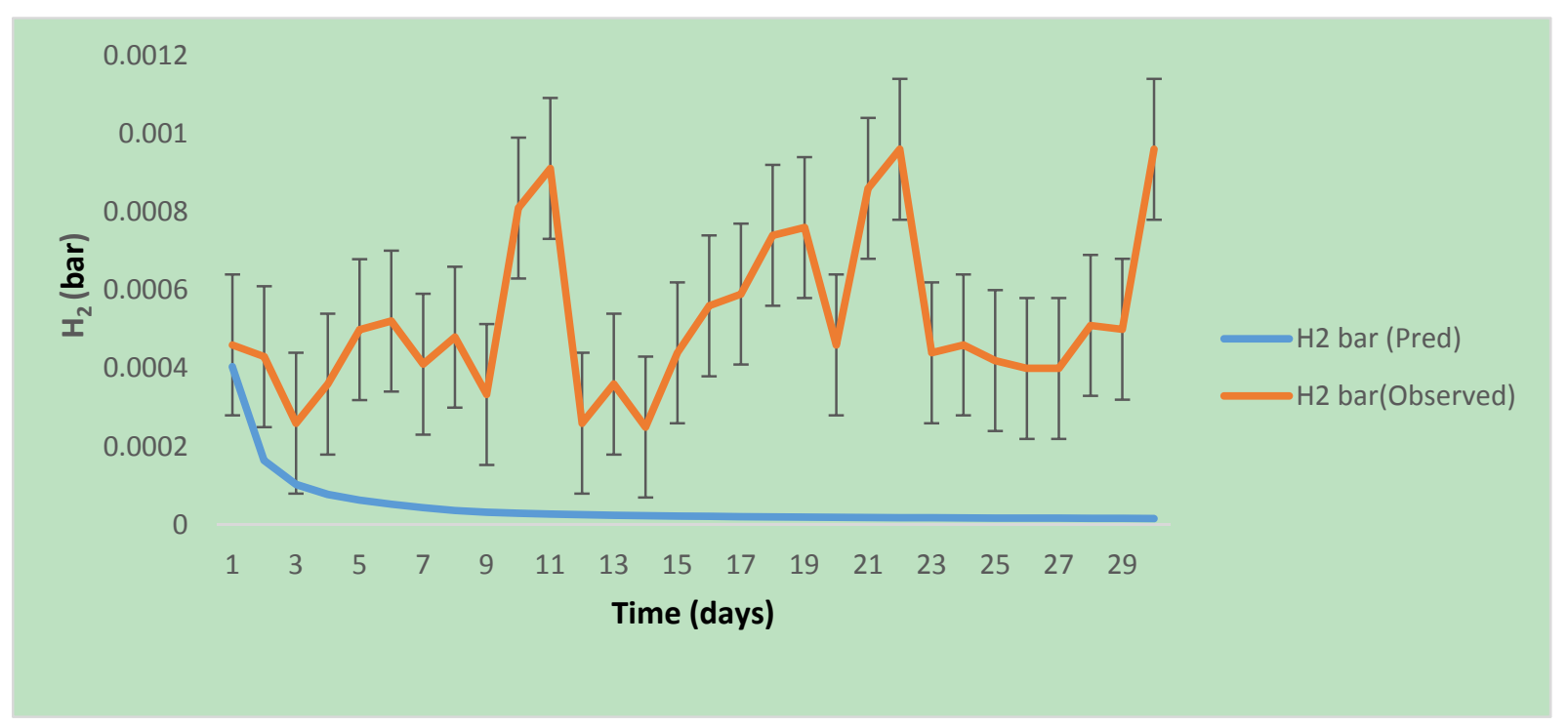

Figure 5. Comparison between predicted and observed $\mathrm{H}_{2}$ (Error Bars = Standard Deviation)

The model successfully predicted $\mathrm{pH}$ values as shown in Figure 2. The values for $\mathrm{pH}$ varied between 7-7.35 which indicates a healthy environment for the digester's microorganisms.

The model's prediction for the VFA concentration was relatively accurate except between days 19 to 24 (Figure 3 ). The reason for the overestimated VFA may be because the oxidation rates coefficients for the VFA were probably overestimated (Parker 2005).

Figure 4 shows the results for observed and predicted biogas and methane gas; the model results overestimated both variables. On the contrary the predicted hydrogen values were underestimated as shown in Figure 5. The model underestimated hydrogen was possibly due to the overestimation of methane gas.

The observed daily variations in all the monitored parameters were as expected since the samples were taken from a functioning, full-scale commercial digester. On the other hand, the predicted parameters and biogas from the ADM1 model didn't show much variation compared to the observed because the values were based on an average inputs for COD, flow, retention time and temperature.

Even though the ADM1 model accurate predictions reflected the trends and general performance of the full-scale digester for the MS (Figure 2-5), the model could not accurately predict the situation of mixed MS and BW. The mechanisms of degradation of carbohydrates, proteins and lipids are not the same in each case; therefore, the model kinetic parameters were modified to reflect the case of mixed MS with BW as discussed in stages 2 to 5 .

\subsection{Stage 2: Adding BW to $M S$}

$10 \% \mathrm{BW}: 90 \% \mathrm{MS}$

Initially, BW was added at a rate of $10 \%$ of the total digester COD for an average of 28 days. Kinetic parameters in the model were modified to take into account the co-digestion of MS and BW to be more appropriate for the mix of both substrates. The model coefficients for carbohydrates, proteins and lipids were changed to reflect the changes in the digester environment (Table 2). Adding BW was expected to enhance methane gas production from the anaerobic digester because BW is composed of easily biodegradable organic matter. The results are shown in Figures 6-8 for 10\% BW. 


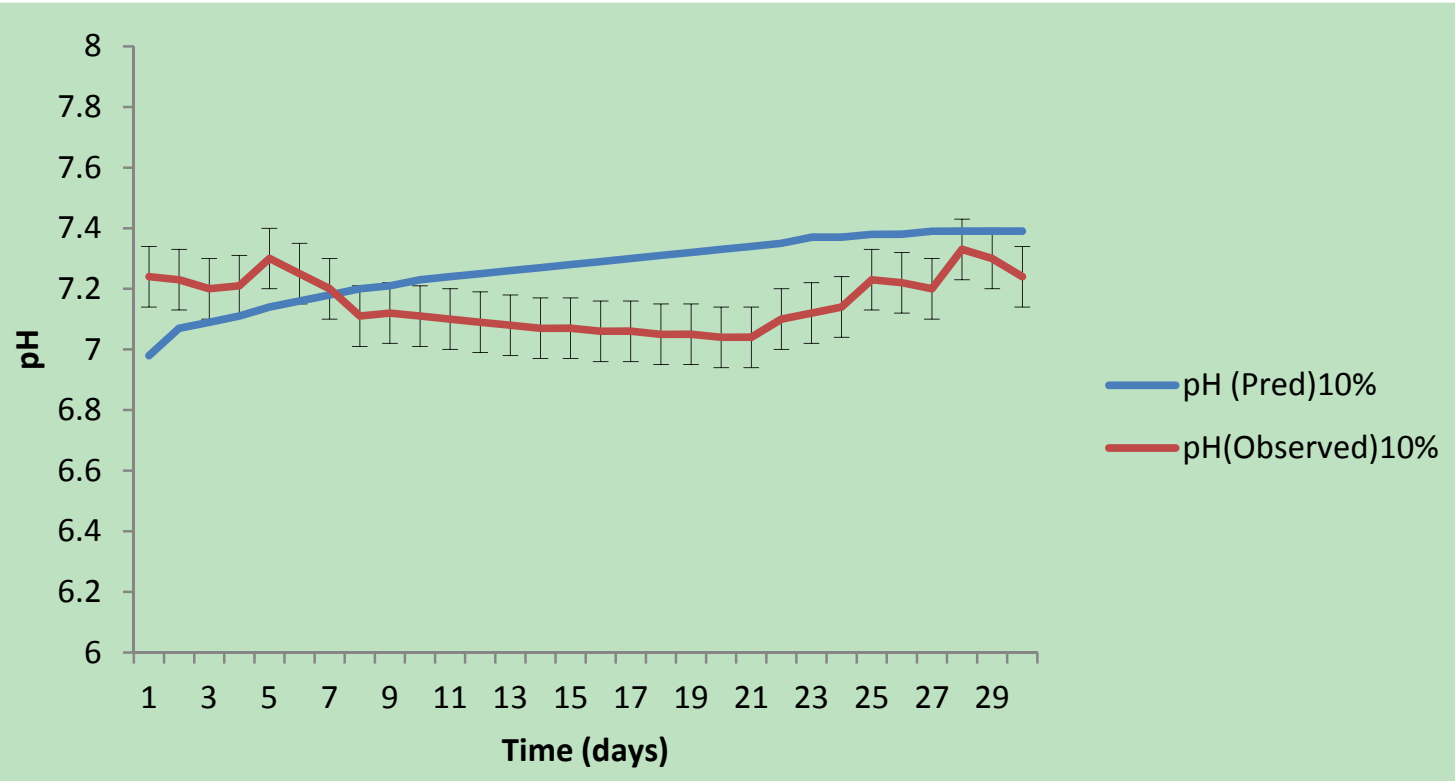

Figure 6. Comparison between predicted and observed pH- 10\% BW (Error Bars= Standard Deviation)

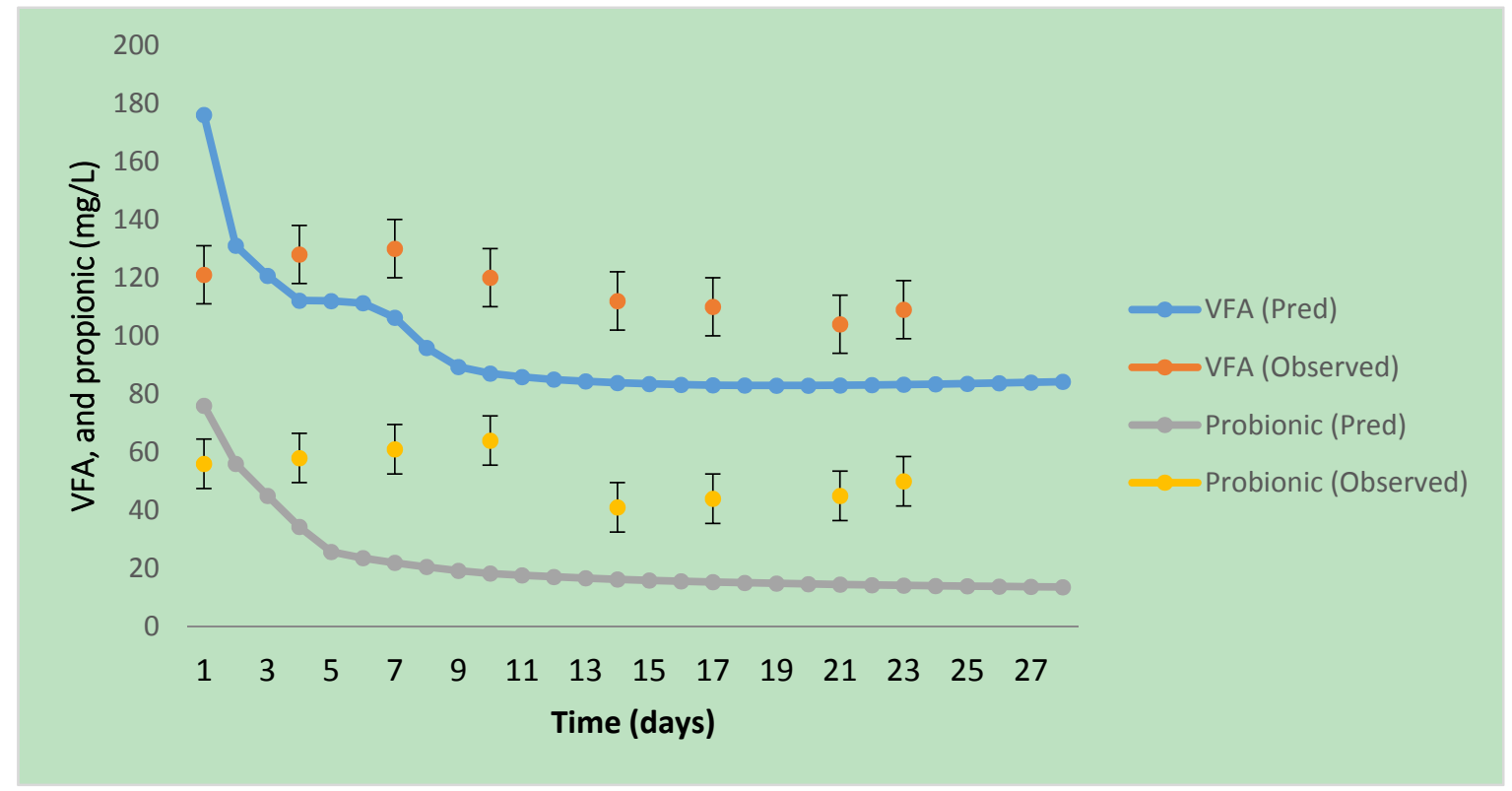

Figure 7. Comparison between predicted and observed VFA, Propionic acid-10\% BW (Error Bars= Standard Deviation) 


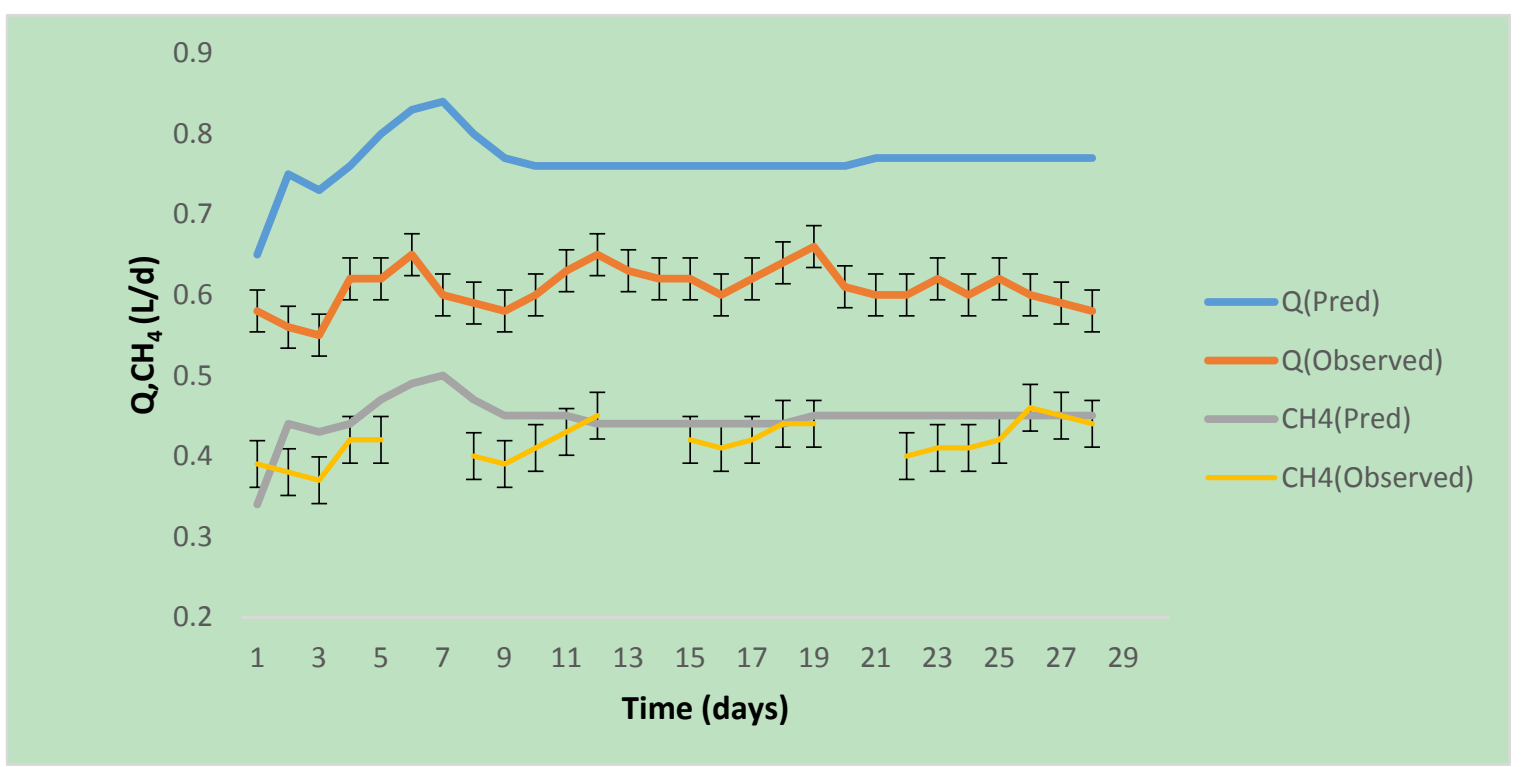

Figure 8. Comparison between predicted and observed Q and $\mathrm{CH}_{4}-10 \% \mathrm{BW}$ (Error Bars= Standard Deviation)

The model accurately predicted the changes in $\mathrm{pH}$ (Figure 6), the $\mathrm{pH}$ results were within the range (6.8-7.2) that indicates a healthy environment for the microorganisms. The model predicted changes in VFA (with propionic acid reported separately) (Figure 7). Based on the model outputs, the concentration of the VFA was $176 \mathrm{mg} / \mathrm{L}$ during the period from day 1 to 5 then dropped to $87 \mathrm{mg} / \mathrm{L}$ on day 10 , and ended with $83 \mathrm{mg} / \mathrm{L}$ for the rest of the days. The propionic acid concentration was $76 \mathrm{mg} / \mathrm{L}$ on day 1 and dropped to $14 \mathrm{mg} / \mathrm{L}$ by day 22 . This indicates that monitoring the digester in the first 10 days of adding $\mathrm{BW}$ is critical because the most significant changes in the digester environment and microorganisms occur during that time. The digester probably needs 10 days to acclimate (the adaptation of the microorganisms with the new substrate). This was also supported by the observed results of the batch reactor; the statistical analysis for observed and predicted data are shown in Table 3.

The model overestimated the biogas produced in this stage, while the predicted methane gas was close to the observed (Figure 8 ). The model estimated the methane percentage content around $58 \%$ of the total biogas, while the observed methane gas was found to be $69 \%$ of the total biogas. Therefore, the eventual stable performance of the digester after the $10 \% \mathrm{BW}$ addition indicated that the digester can accommodate at least this much added BW.

\subsection{Stage 3: Adding $B W$ to $M S$ \\ $20 \% \mathrm{BW}: 80 \% \mathrm{MS}$}

Figures 9-11 show predicted and observed changes in the digester when 20\% BW as COD was added to the batch reactor scale. The predicted values for $\mathrm{pH}, \mathrm{VFA}$, propionic acid, biogas, and methane gas from the model remained within an acceptable range. Statistical results are shown in Table 3. In this stage, there was no indication of inhibition or toxicity to the microorganisms because the $\mathrm{pH}$ values were found to be neutral. VFA and propionic acid were less than the critical concentrations $(2000 \mathrm{mg} / \mathrm{L}, 300 \mathrm{mg} / \mathrm{L}$ respectively). Therefore, $20 \%$ of BW was acceptable for the digester optimum performance. 


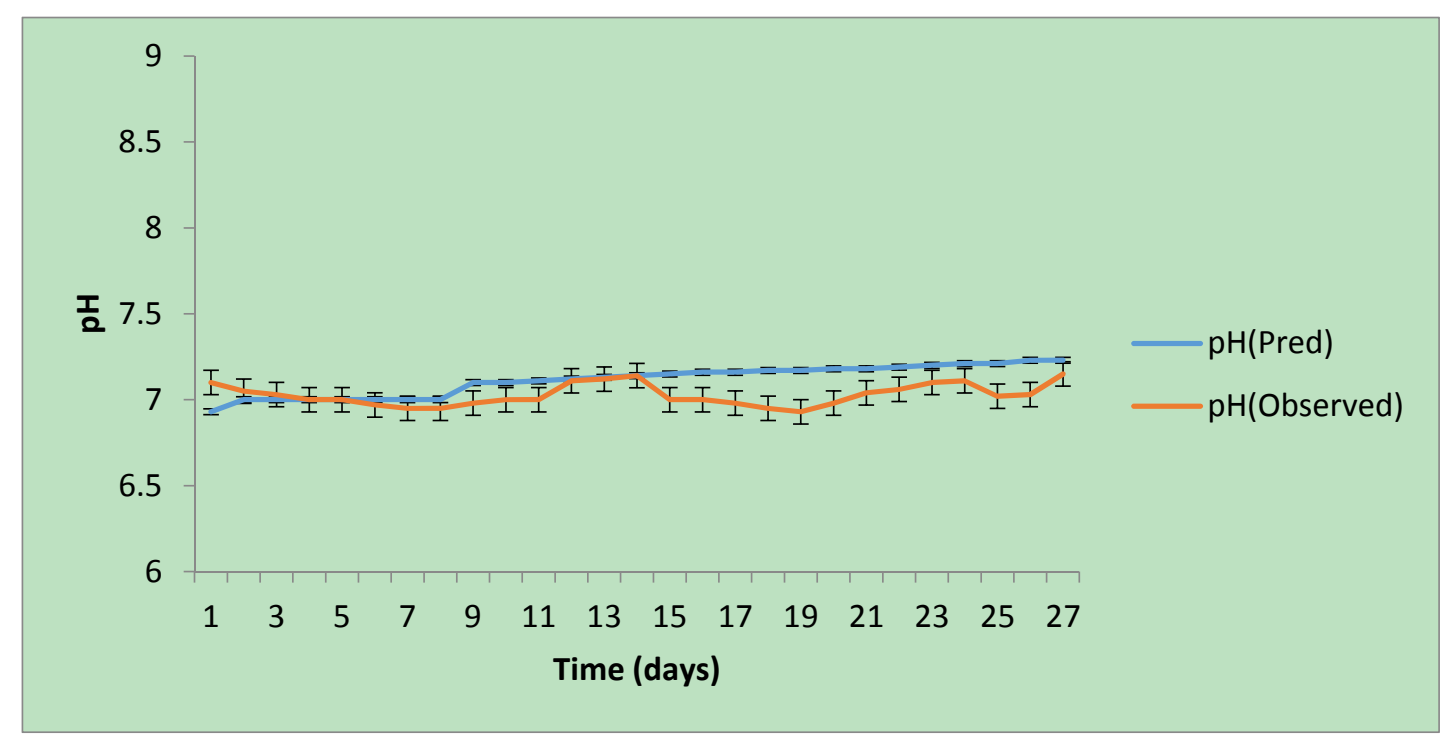

Figure 9. Comparison between predicted and observed pH- 20\% BW (Error Bars= Standard Deviation)

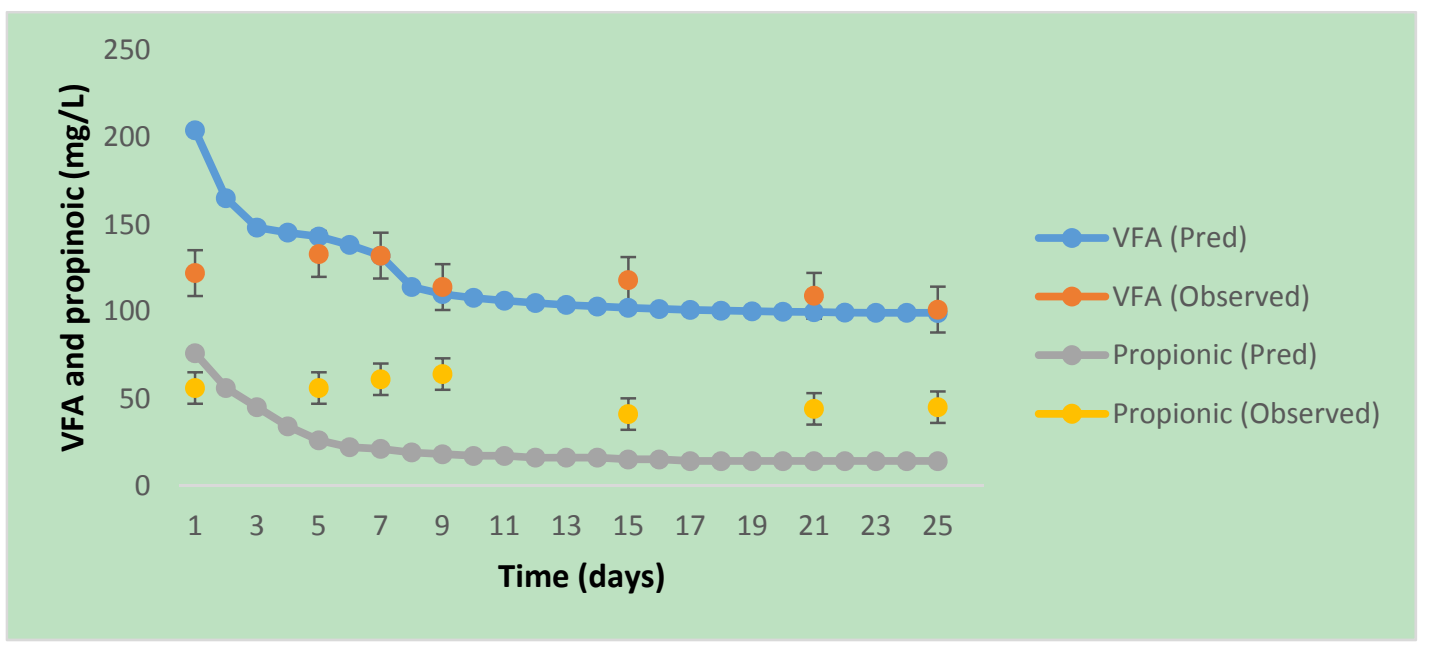

Figure 10. Comparison between predicted and observed VFA and propionic acid- 20\% BW (Error Bars= Standard Deviation) 


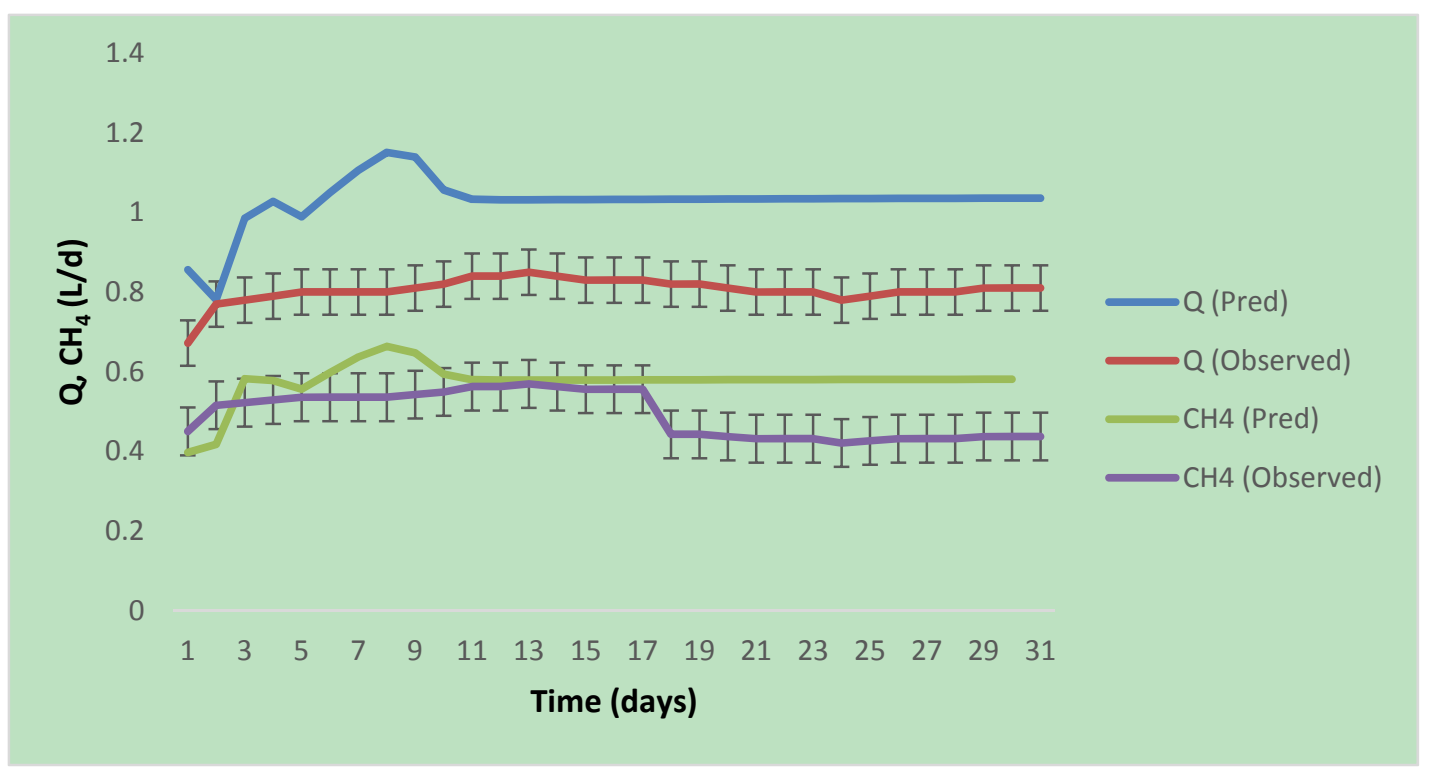

Figure 11. Comparison between predicted and observed Q and $\mathrm{CH}_{4}-20 \% \mathrm{BW}$ (Error Bars= Standard Deviation)

\subsection{Stage 4: Adding BW to $M S$}

$30 \% \mathrm{BW}: 70 \% \mathrm{MS}$

At this stage, the $\mathrm{BW}$ load was increased to $30 \%$ and the parameters were monitored to evaluate the digester behavior with the increase in the BW percentage. Figures 12-14 show the results with 30\% BW.

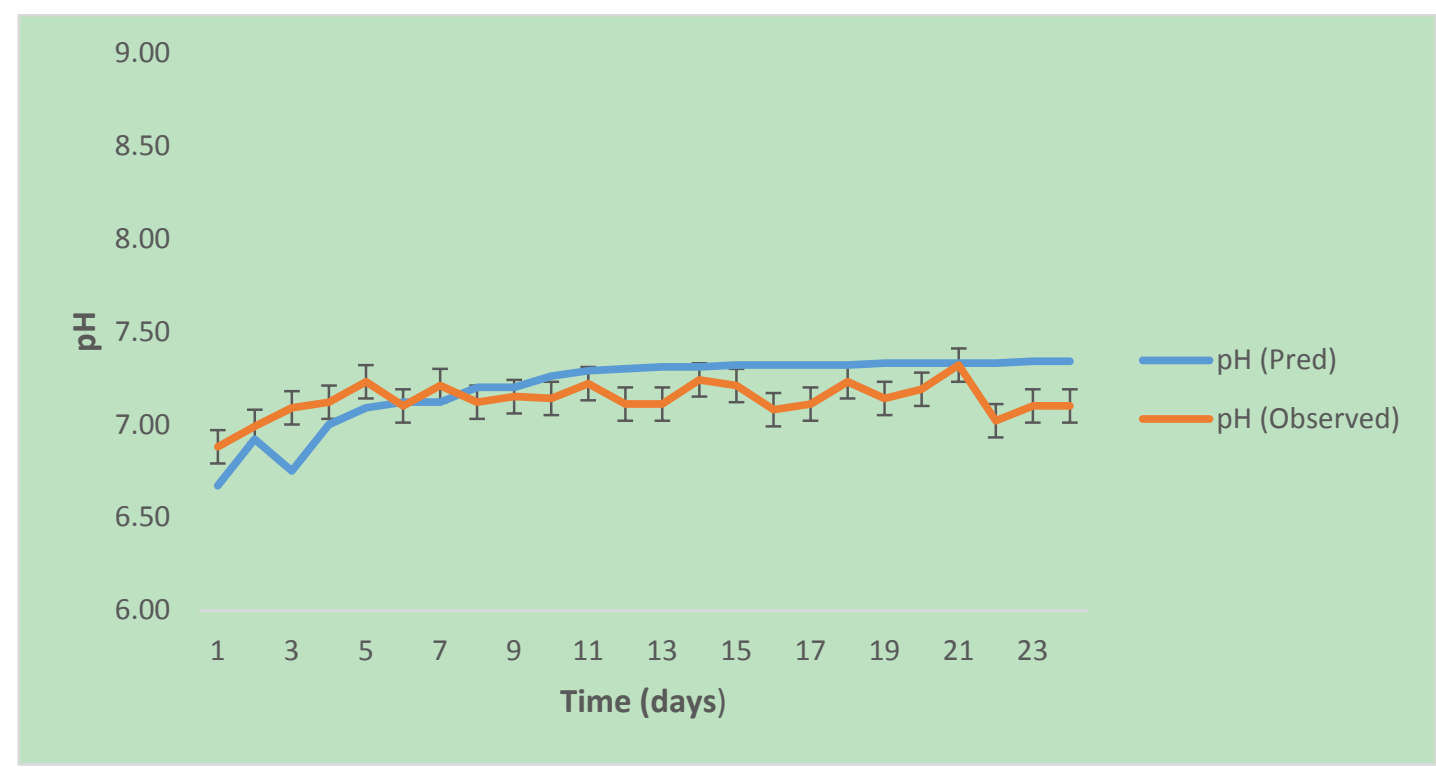

Figure 12. Comparison between predicted and observed pH- 30\% BW (Error Bars= Standard Deviation) 


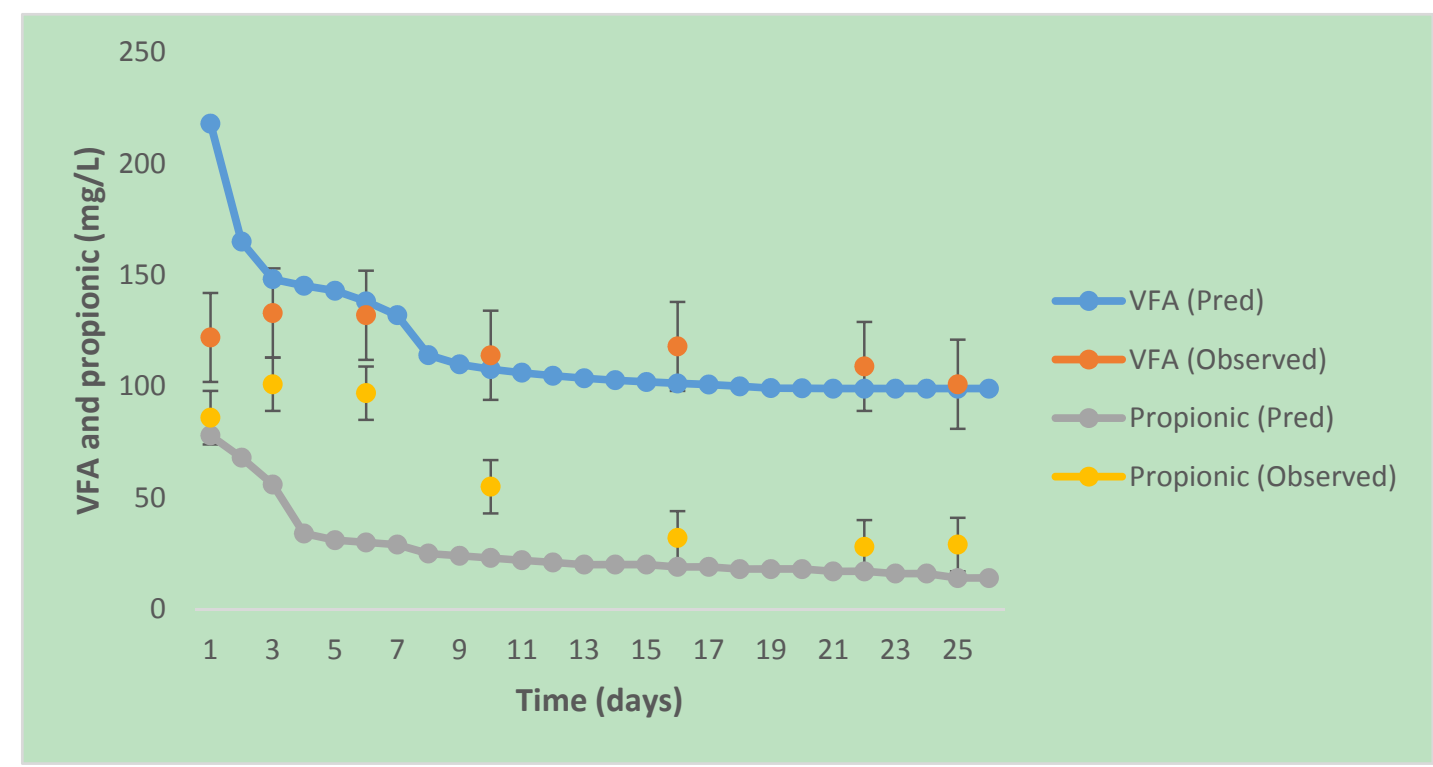

Figure 13. Comparison between predicted, observed VFA and propionic acid- 30\% BW (Error Bars= Standard Deviation)

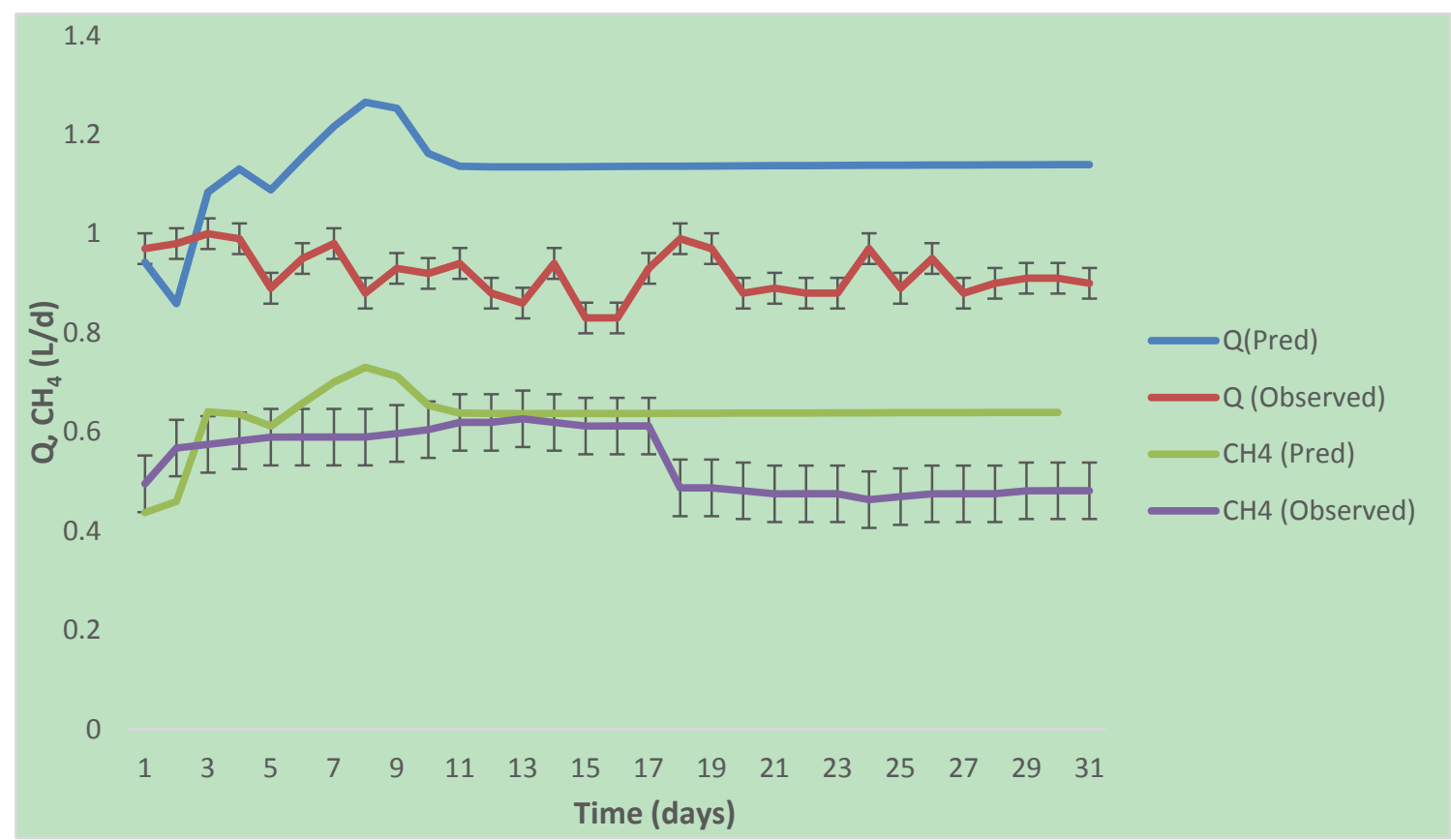

Figure 14. Comparison between predicted, observed Q and $\mathrm{CH}_{4}-30 \% \mathrm{BW}$ (Error Bars= Standard Deviation)

The $\mathrm{pH}$ values were low for the first 4 days; then the $\mathrm{pH}$ values returned to neutral. VFA and propionic acid concentrations were below the critical concentrations for the microorganisms. The model was able to predict the methane gas in acceptable range; the statistical analysis results are shown in Table 3.

The Figures (15-17) show the variation of $\mathrm{pH}$, VFA, and methane gas for all the stages when no BW added and with $10 \%, 20 \%$ and $30 \%$ of BW addition. 


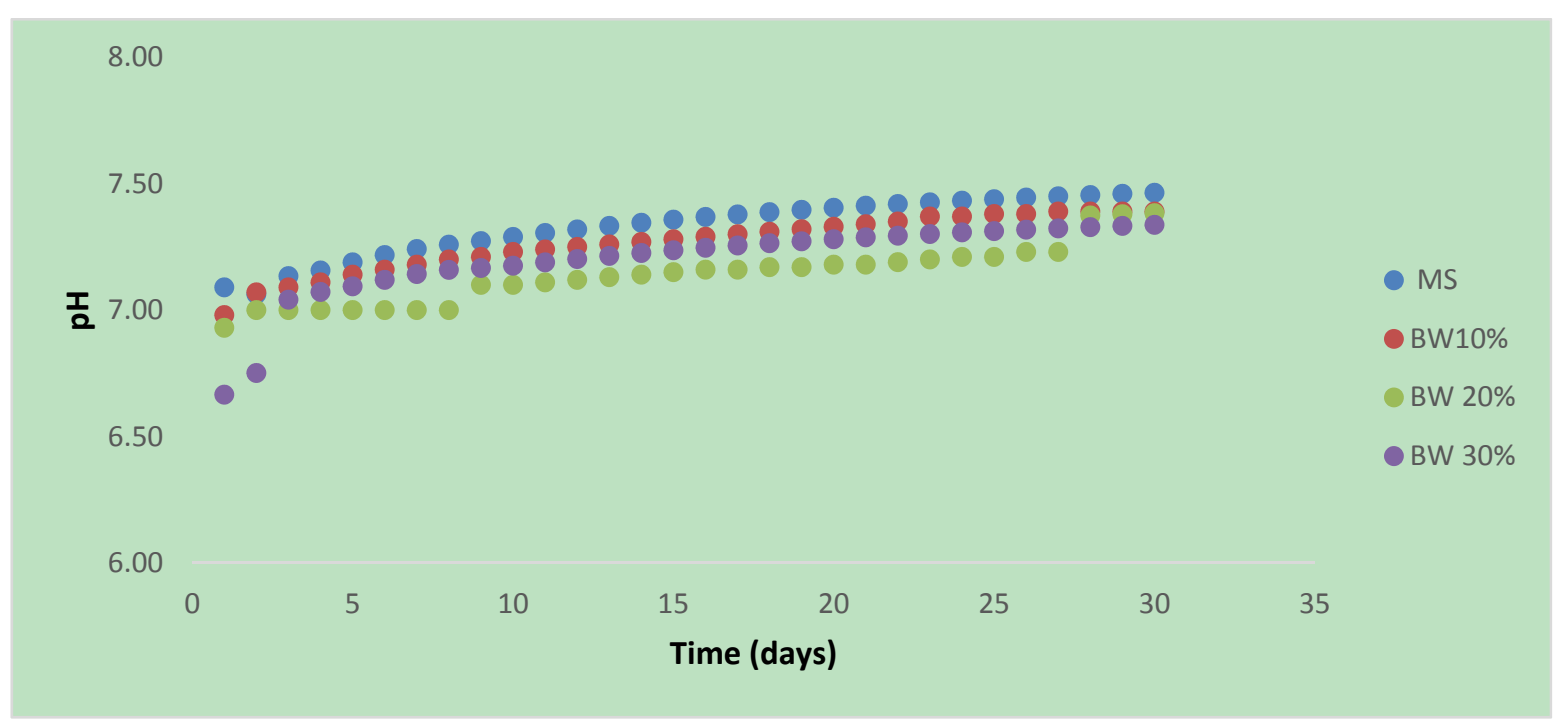

Figure 15 . The variation of $\mathrm{pH}$ with time $(0 \%, 10 \%, 20 \%$ and $30 \% \mathrm{BW})$

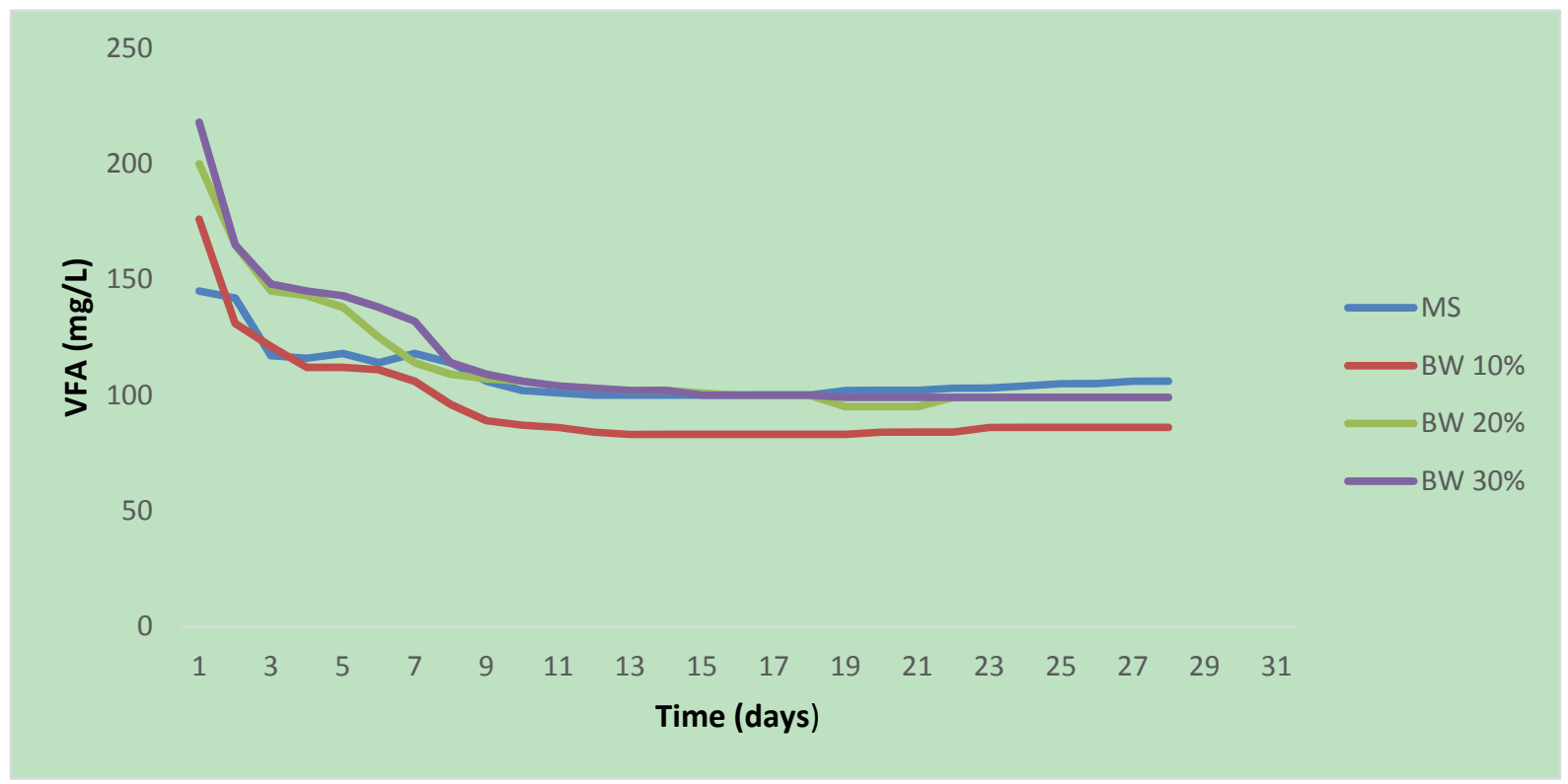

Figure 16. The variation of VFA with time $(0 \%, 10 \%, 20 \%$ and $30 \% \mathrm{BW})$ 


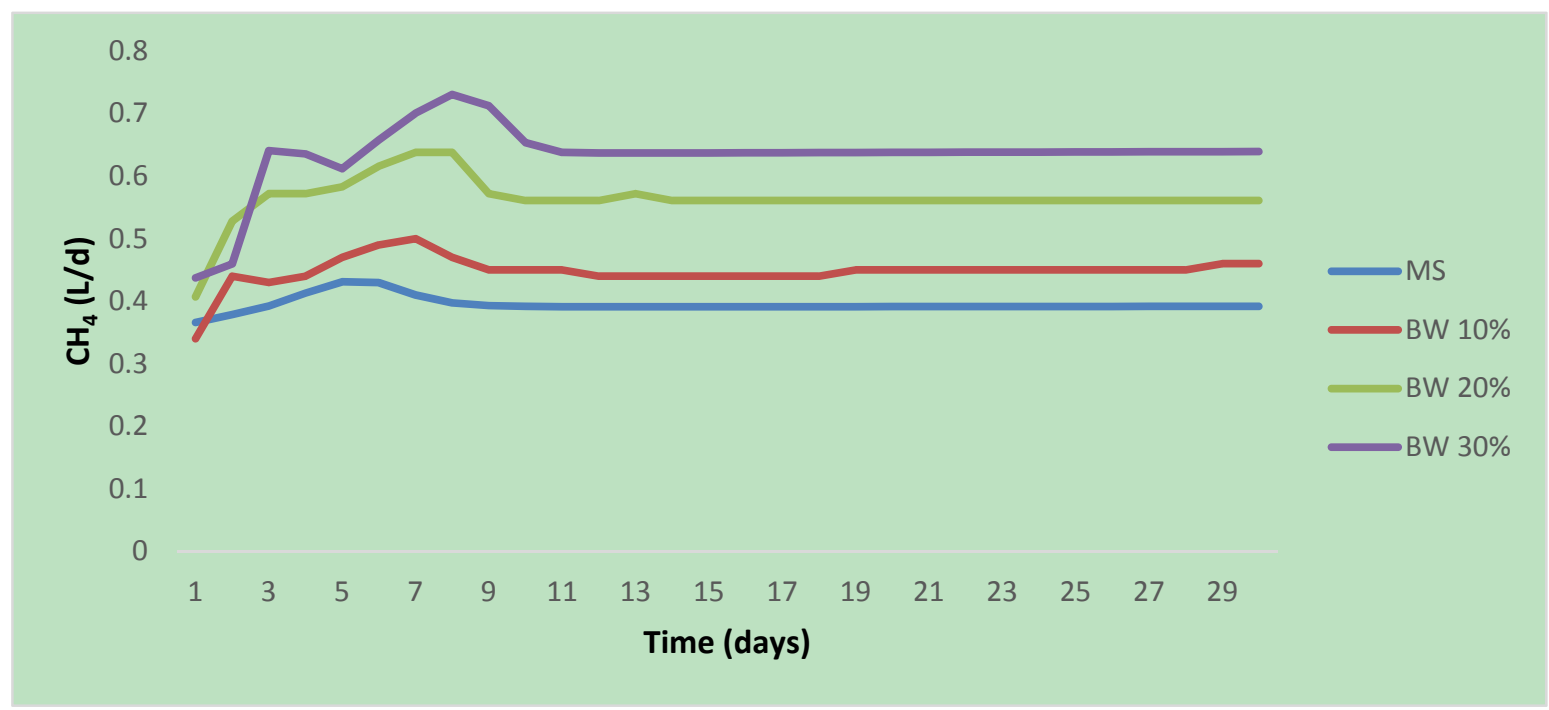

Figure 17. The variation of $\mathrm{CH}_{4}$ with time $(0 \%, 10 \%, 20 \%$ and $30 \% \mathrm{BW})$

Figure 15 shows the variation in the $\mathrm{pH}$ with sludge only and the sludge with different ratios of $\mathrm{BW}(10 \%, 20 \%$, and $30 \%$ ). Injecting BW led to a slight drop in the $\mathrm{pH}$ during the first 8 days, particularly with the higher loads of BW $(20 \%, 30 \%)$, then no significant variation in the $\mathrm{pH}$ values were observed for the rest of the experiment days, which indicates a healthy environment for the anaerobic microorganisms inside the digester. The natural buffer of the system is important for maintaining the $\mathrm{pH}$ close to neutral even when a drop occurs.

MS provides the required buffer since BW alkalinity is very low (Table 1 , BW alkalinity as $\mathrm{CaCO}_{3}=45 \pm 6.4$ $\mathrm{mg} / \mathrm{L}$ ). The natural buffer occurs due to the process of proteins degradation which provides the system with ammonia $\left(\mathrm{NH}_{3}\right)$. The ammonia, reacts with the excess of hydrogen protons to keep the $\mathrm{pH}$ values neutral as illustrated by Equation 1 (Burton 2004).

$$
\mathrm{NH}_{3}+\mathrm{H}^{+} \rightarrow \mathrm{NH}_{4}^{+}
$$

In this study, it was found that the $\mathrm{pH}$ values were neutral with the different BW loads (Figure 15). No external buffer (lime or soda ash) was required to maintain the $\mathrm{pH}$ of the system, which makes the overall economic cost-effectiveness of the process favorable.

The variation of VFA with the increase of BW loads from $10 \%-30 \%$ was illustrated in Figure 16. VFA concentrations increased (176-218 mg/L) due to the impact of BW especially during the first 10 days. The concentration of the VFA dropped down to an average of $100 \mathrm{mg} / \mathrm{L}$ for the rest of the days (Figure 16).

The advantage of adding BW is further revealed in Figure 17. An increase in methane gas production from the digester was noticeable with increased percentage of BW. The average daily production of methane gas was 0.39 $\mathrm{L} / \mathrm{d}$ when MS was used; methane production was increased to an average of $0.64 \mathrm{~L} / \mathrm{d}$ when $30 \% \mathrm{BW}$ was used, confirming the enhancement of the methane production by approximately $60 \%$ compared to MS.

\subsection{Stage 5: Adding $B W$ to $M S$}

\section{[35\%, 36\%, 37\%, 40\%, 42\% and 44\% BW]: [65\%, 64\%, 63\%, 60\%, 58\%, and $56 \% \mathrm{MS}$ ]}

Using the modified parameters in Table 2 in order to determine the imbalance point of the digester, the ADM1 model was run with the ratios $35 \%, 36 \%, 37 \%$, and $40 \%$ of BW with MS based on COD. The imbalance point based on the model results was reached with the ratio of 37\% BW: 63\% MS. Figures 18-20 show the failure points as predicted by the model. 


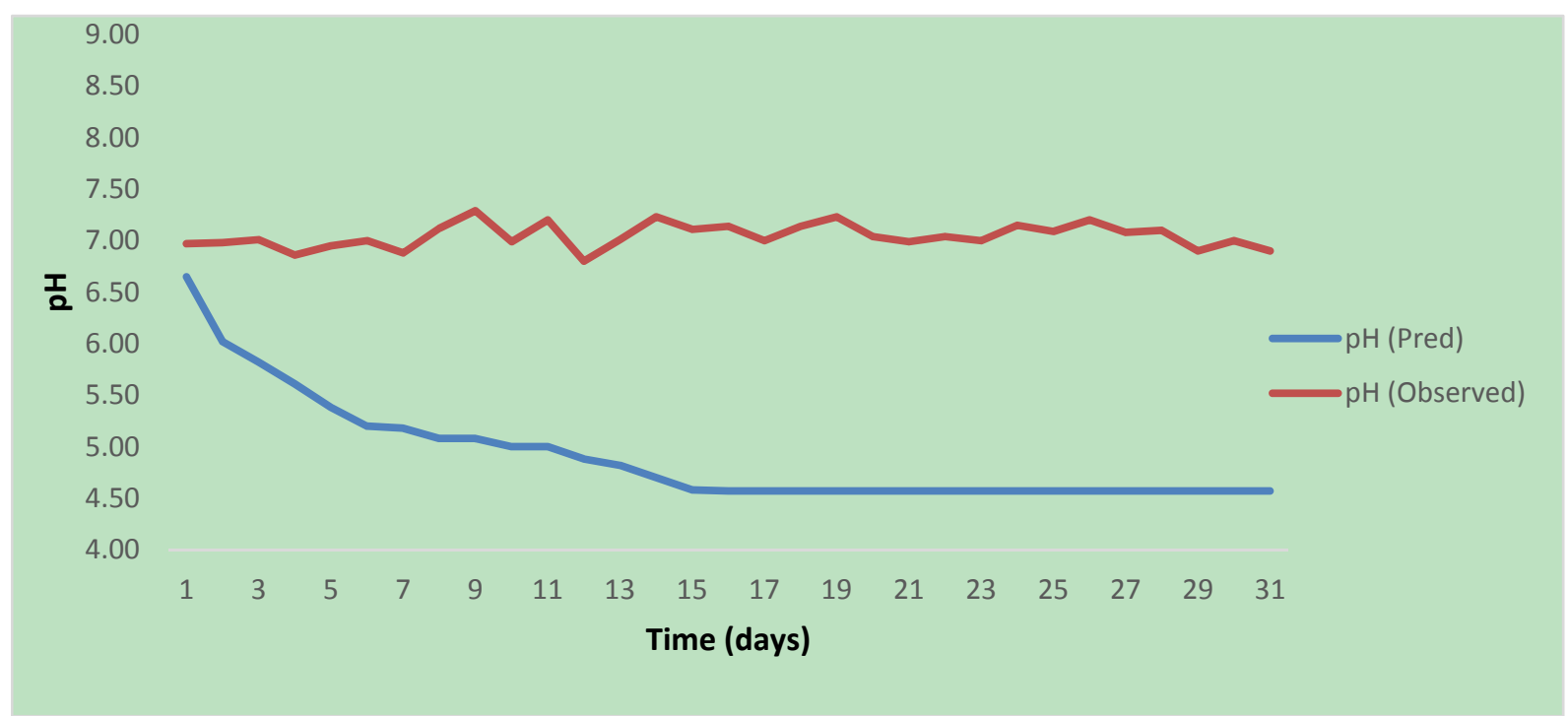

Figure 18. Comparison between predicted and observed $\mathrm{pH}-37 \% \mathrm{BW}$

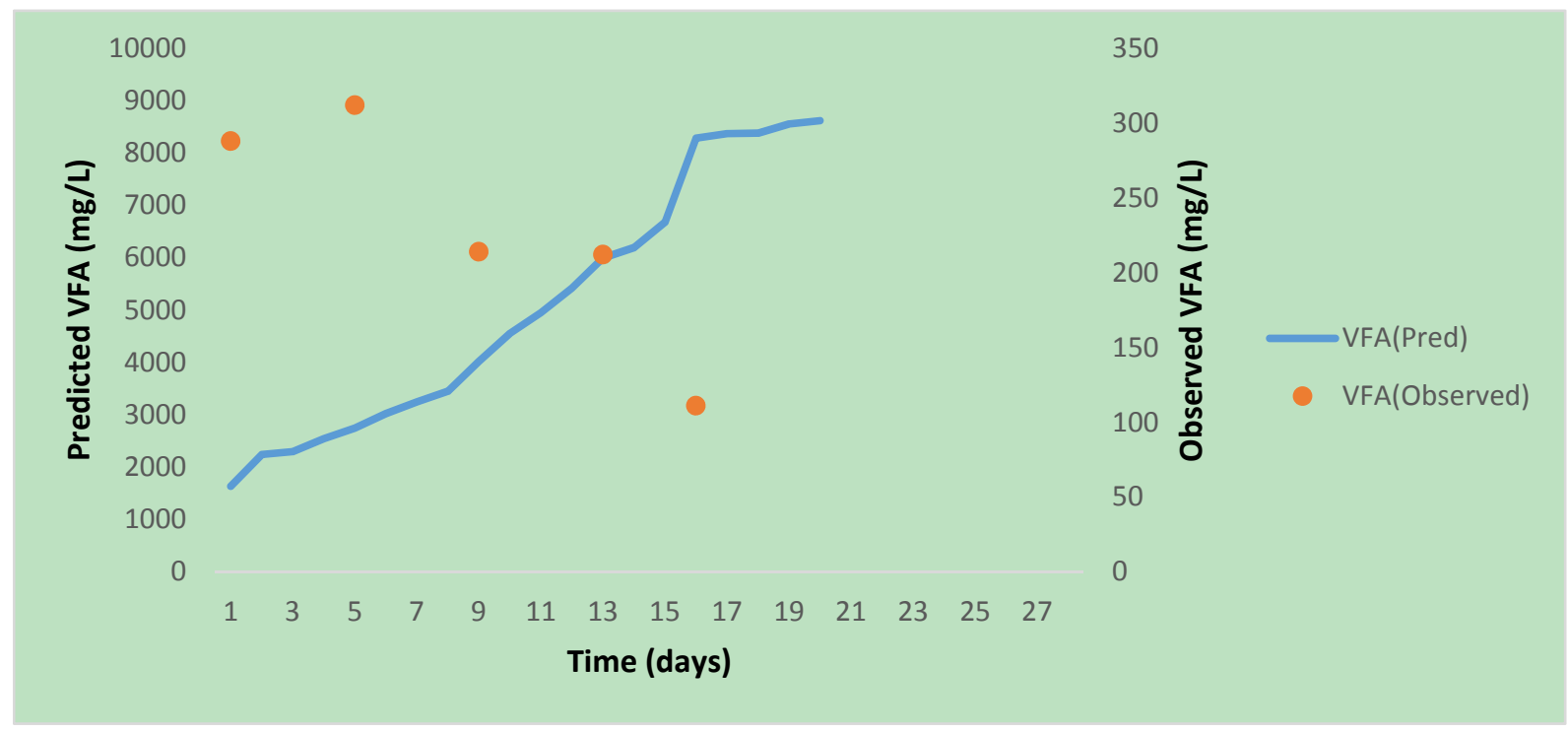

Figure 19. Comparison between predicted and observed VFA- 37\% BW 


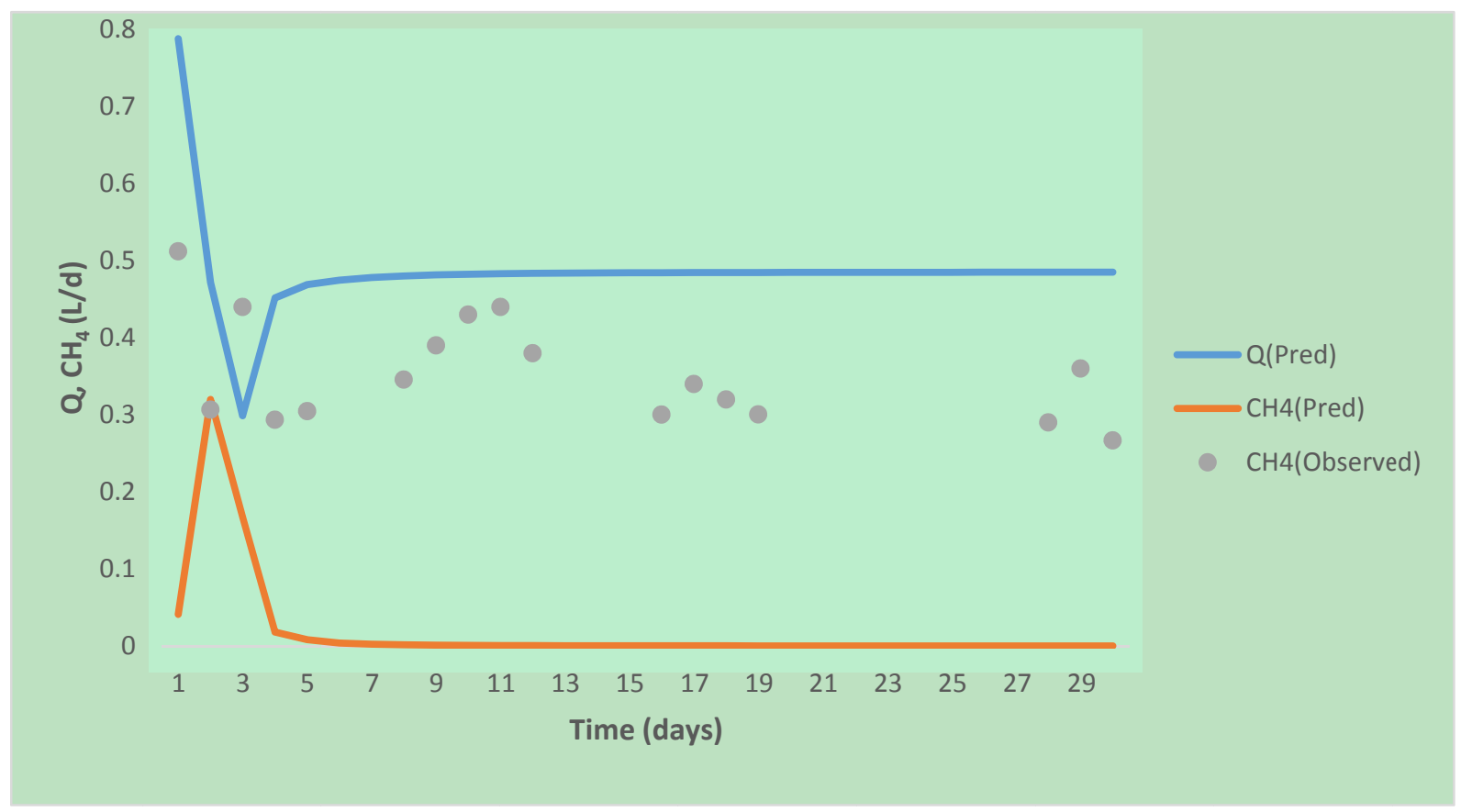

Figure 20. Comparison between predicted and observed Q, $\mathrm{CH}_{4}-37 \% \mathrm{BW}$

Based on the model results, the BW would drop the $\mathrm{pH}$ to 4.57 , VFA would reach $8618 \mathrm{mg} / \mathrm{L}$, and $0 \%$ methane gas would be produced. However, with this ratio (37\% BW: $63 \% \mathrm{MS})$ in the batch reactors, the $\mathrm{pH}$ values were still close enough to neutral. Moreover, the measured VFA and methane gas produced indicated no failure detection at this ratio of $\mathrm{BW}$ to sludge (37\%: 63\%) in the batch reactor scale.

In order to reduce the uncertainty associated with the co-digestion of BW and to determine the failure point of the digester, the batch reactors were run again with $40 \%, 42 \%$, and $44 \% \mathrm{BW}$. The results of the batch reactors showed a huge drop in the $\mathrm{pH}$ and methane gas with the mixing ratio of $40 \% \mathrm{BW}: 60 \% \mathrm{MS}$.

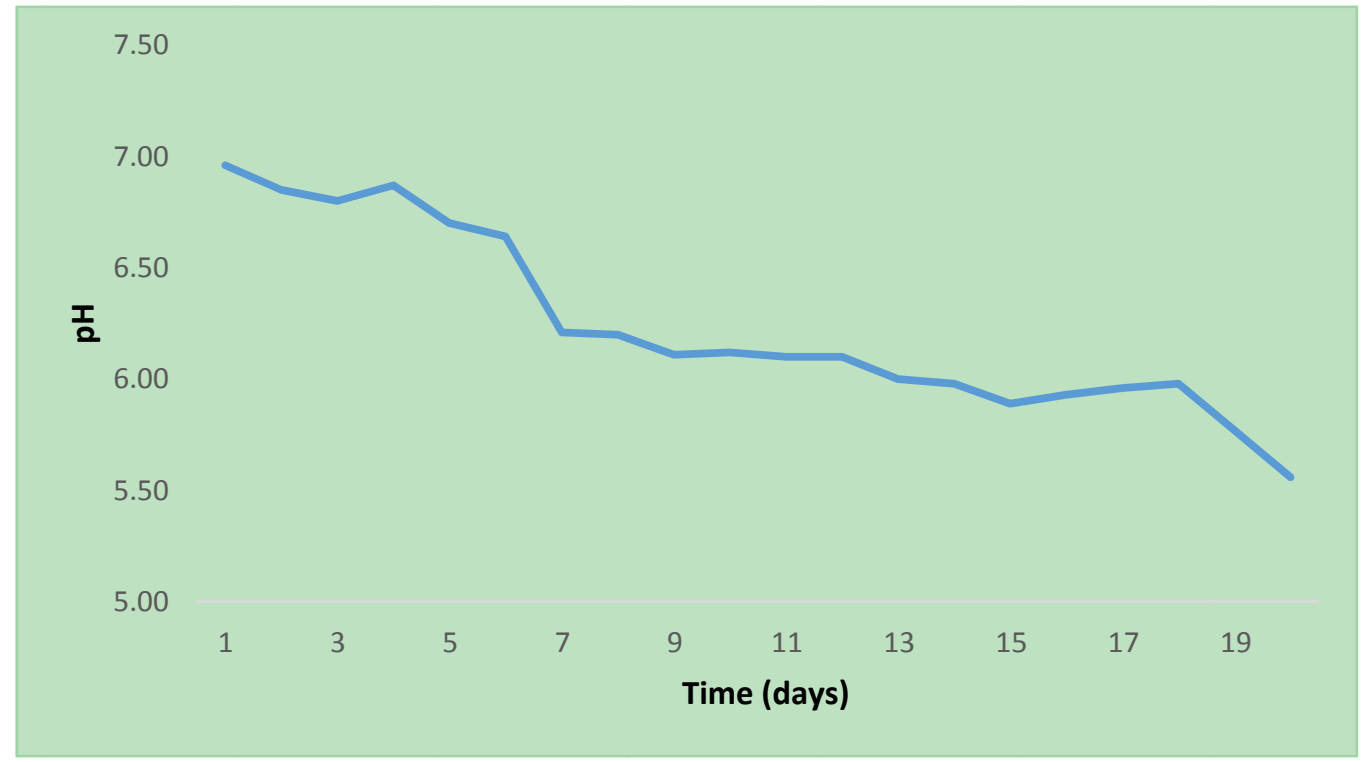

Figure 21. The variation of $\mathrm{pH}$ with time- $40 \% \mathrm{BW}$ 


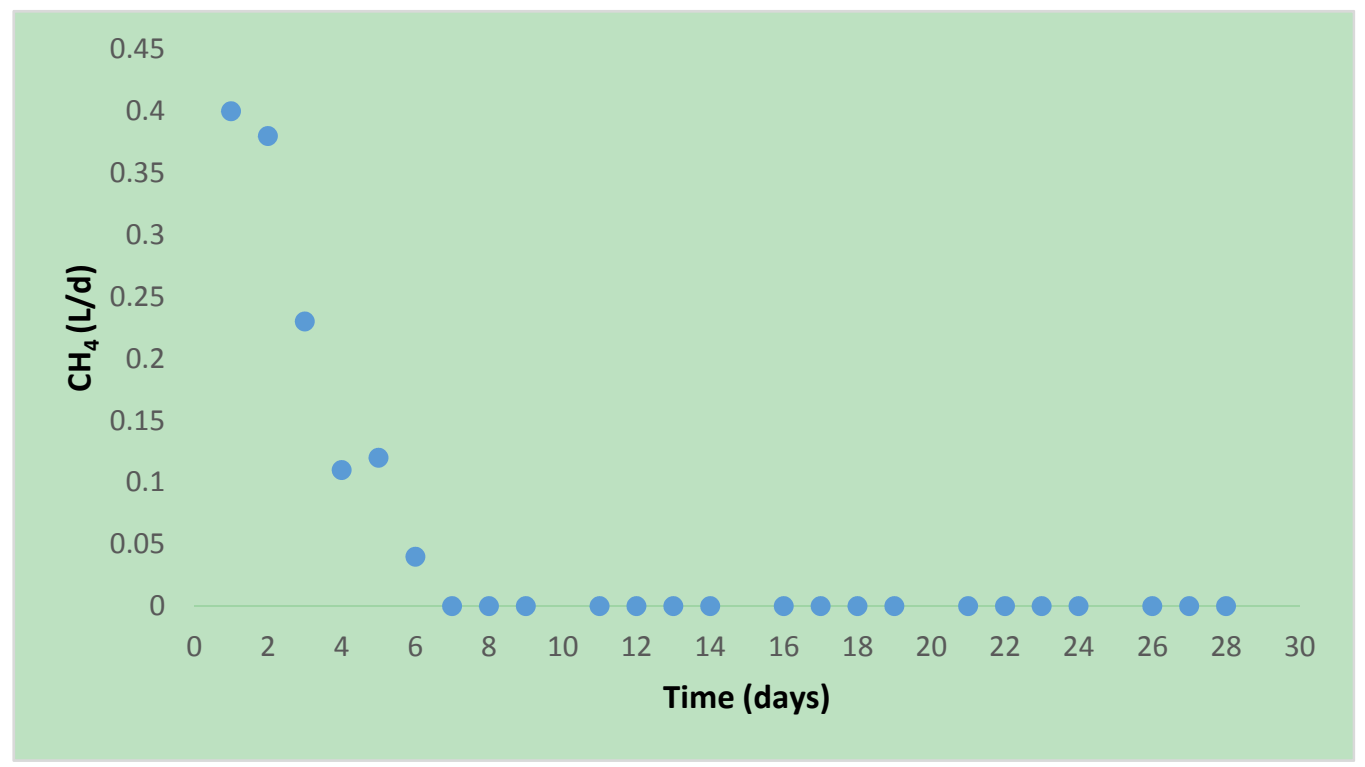

Figure 22. $\mathrm{CH}_{4}$ variation with time- $40 \% \mathrm{BW}$

Based on batch reactor results, the imbalance point was reached at $40 \% \mathrm{BW}$. There was a drop in the $\mathrm{pH}$ to 5.56 after 20 days of the experiment, and methane gas was not detectable after 7 days.

The results of this study confirm that BW is an attractive material that can enhance the production of methane gas when mixed with MS. Although caution must be taken to avoid adding too much BW to MS in order to avoid reactor failure. It was found that the digester is capable of maintaining stability until the maximum range of $37-40 \%$ BW to $63 \%-60 \%$ MS ratios (based on COD). Both results (model and experimental) reduced the uncertainty and the risk associated with BW to MS co-digestion.

It is important to use batch reactor experiments to determine the stability and the impact of adding BW because BW may contain material toxic to the microorganism community in the reactor, which may not be detected by the ADM1 model. BW also contains a significant amount of metals, which may have negative impact on the microorganisms when co-mixed with MS and this too cannot be detected by the model.

Metals like $\mathrm{Na}^{+}$may inhibit the microorganisms when they reach high concentrations (Hierholtzer and Akunna 2012), while $\mathrm{Cl}^{-}$and $\mathrm{SO}_{4}{ }^{-2}$ may form various inhibitors when they interact with other metals inside the digester (Ye Chen 2007); the modified ADM1 model is unable to detect such inhibitors if found.

The increase in the VFA concentrations was the main reason for the digester failure. Increasing the loads of BW mixed with MS leads to an increase in the VFA, which drops the $\mathrm{pH}$. Another reason that may have contributed to digester failure when $37 \%-40 \%$ BW was added was the $\mathrm{C} / \mathrm{N}$ ratio. The $\mathrm{C} / \mathrm{N}$ ratio for optimum digestion and optimal gas production should be 25-30:1(Polprasert 1989), though in other studies, the $\mathrm{C} / \mathrm{N}$ was found to be 700:5 (Sahm et al. 1985; Seghezzo et al. 1998). The main source of the $\mathrm{N}$ in the co-digestion of BW with MS is the proteins content of the MS. Since BW doesn't include proteins (Table 1, TKN and $\mathrm{NH}_{3}$ were below the detection limit), the only source of $\mathrm{N}$ was the MS.

Based on the results of this study, BW mixed with MS has less nitrogen content and that has less effect on the digester stability due to ammonia (low proteins in the BW). Thus, BW can be considered an advantage co-mixed with MS compared to food waste.

BW contains about $20 \%$ lipids which is less than most food waste (30\% approximately). Lipids degrade to long chain fatty acids by bacterial activities, and high concentrations of long chain fatty acids are inhibitory to anaerobic microorganisms (Tritt 1992). Lipid-rich material like food wastes from restaurants is not appropriate for municipal digesters since it can readily accumulate inside the digester walls, forming hardened deposit material and reducing the digester volume capacity (He et al. 2011). BW, on the other hand, are not sufficiently lipid - or proteins-rich to cause this problem.

Furthermore, keeping BW from disposing and utilizing them in the way discussed in this research, as good substrate for co-digestion is also beneficial because it is highly rich in organic matter, easily biodegradable, and can be easily pumped (as slurry material). The BW creates good balance with the MS, avoiding most of the 
inhibitors and toxicants and leads to a high methane production and acceptable process co-digestion stability when mixed within proper ratio limits.

\section{Conclusion}

The ADM1 is a strong tool for predicting and simulating the performance of the anaerobic digester when treating mixed substrate (MS with BW). Modification and validation were applied to the model in order to accurately predict the impact of adding the BW to MS. The modification of the kinetic parameters of the model improved the ADM1 to become more appropriate for the prediction of the mixed substrate (MS + BW).

Stable performance of the digester was confirmed with $10 \%, 20 \%$, and $30 \%$ of BW addition to MS. The $\mathrm{pH}$, VFA, and propionic acid from observed and predicted results were in the recommended range which reflect a healthy environment for the microorganisms in the digester. An increase in methane gas production (up to 60\%) was observed as a result of adding BW.

The imbalanced range of the digester occurred between $37 \%-40 \%$ BW to MS ratios, based on observed and predicted results of the modified model, and no inhibition was detected before that range.

This research developed an existing mathematical model (ADM1) for addressing the addition of a specific substrate (BW) to MS, in order to reduce the risk and the uncertainty of the digester's malfunction where this substrate actually employed on a large scale.

\section{Recommendations}

(1) Reclamation of BW will play an important role in its management, it is rich in organic matter and can be applied to produce energy instead of disposals, which will be an environmental benefit to the public.

(2) Further improvement for the ADM1 model is required, to more accurately predict the biogas and hydrogen gas production during the process. Modeling accurately the hydrogen gas is important because hydrogen has a negative impact on the acidogensis bacteria, and it results in an early stress of the system.

\section{Acknowledgements}

I would like to thank the Utah Water Research Laboratory for their financial support and supervision, Central Weber Sewer Improvement District for the permission to use their facility and to present the data, CSM Bakery Products for the permission to collect the data, Dr. Darwin Sorensen and Dr. David K. Stevens from the Utah Water Research Laboratory for their encouragement and help with this research.

\section{References}

APHA, A. P. H. A. (2005). Standard Methods for the Examination of Water and Waste Water. Washington, DC.

Batstone, D. J., \& Keller, J. (2003). Industrial applications of the IWA anaerobic digestion model No. 1 (ADM1). Water Sci Technol, 47(12), 199-206.

Batstone, D. J., Keller, J., Angelidaki, I., Kalyuzhnyi, S. V., Pavlostathis, S. G., Rozzi, A., Sanders, W. T. M., Siegrist, H., \& Vavilin, V. A. (2002). The IWA Anaerobic Digestion Model No 1 (ADM1). Water Sci Technol, 45(10), 65-73.

Bitton, G. (2011). Wastewater Microbiolgy. John Wiley and Sons Inc., New York, NY.

Burton, G. T. a. F. L. (2004). Wastewater Engineering Treatment and Reuse. Metcalf \&amp; Eddy Inc.

Callaghan, F. J., Wase, D. A. J., Thayanithy, K., \& Forster, C. F. (1999). Co-digestion of waste organic solids: batch studies. Bioresource technology, 67(2), 117-122. http://dx.doi.org/10.1016/S0960-8524(98)00108-4

Chen, Y., Cheng, J. J., \& Creamer, K. S. (2008). Inhibition of anaerobic digestion process: a review. Bioresource technology, 99(10), 4044-4064. http://dx.doi.org/10.1016/j.biortech.2007.01.057

Demirel, B., \& Yenigun, O. (2002). Two-phase anaerobic digestion processes: a review. Chemical technology and biotechnology, 77, 747-759. http://dx.doi.org/10.1002/jctb.630

Dupla, M., Conte, T., Bouvier, J. C., Bernet, N., \& Steyer, J. P. (2004). Dynamic evaluation of a fixed bed anaerobic digestion process in response to organic overloads and toxicant shockloads. Water Sci Technol, 49(1), 61-68.

Fang, C., Boe, K., \& Angelidaki, I. (2011). Anaerobic co-digestion of desugared molasses with cow manure; focusing on sodium and potassium inhibition. Bioresource technology, 102(2), 1005-1011. http://dx.doi.org/10.1016/j.biortech.2010.09.077

Fountoulakis, M. S., Petousi, I., \& Manios, T. (2010). Co-digestion of sewage sludge with glycerol to boost 
biogas production. Waste Management, 30(10), 1849-1853. http://dx.doi.org/10.1016/j.wasman.2010.04.011

Gary Amy, D. B., Comaeu, Y., Ekama, G. A., Gerba, C., Judd, S., Wentzell, M. Z., \& Zeeman, G. (2008). Biological Wastewater Treatment, Principles, Modeling and Design. IWA Publishing, London, UK.

He, X., Iasmin, M., Dean, L. O., Lappi, S. E., Ducoste, J. J., \& de los Reyes, F. L. (2011). Evidence for Fat, Oil, and Grease (FOG) Deposit Formation Mechanisms in Sewer Lines. Environmental Science \& Technology, 45(10), 4385-4391. http://dx.doi.org/10.1021/es2001997

Henze, M. (2008). Biological wastewater treatment : principles, modelling and design. IWA Pub., London.

Hierholtzer, A., \& Akunna, J. C. (2012). Modelling sodium inhibition on the anaerobic digestion process. Water Sci Technol, 66(7), 1565-1573. http://dx.doi.org/10.2166/wst.2012.345

Jiang, J., Zhang, Y., Li, K., Wang, Q., Gong, C., \& Li, M. (2013). Volatile fatty acids production from food waste: effects of $\mathrm{pH}$, temperature, and organic loading rate. Bioresource technology, 143, 525-530. http://dx.doi.org/10.1016/j.biortech.2013.06.025

Kabouris, J. C., Tezel, U., Pavlostathis, S. G., Engelmann, M., Dulaney, J., Gillette, R. A., \& Todd, A. C. (2009). Methane recovery from the anaerobic codigestion of municipal sludge and FOG. Bioresource technology, 100(15), 3701-3705. http://dx.doi.org/10.1016/j.biortech.2009.02.024

Kabouris, J. C., Ulas, T., Pavlostathis, S. G., Engelmann, M., Todd, A. C., \& Gillette, R. A. (2008). The Anaerobic Biodegradability of Municipal Sludge and Fat, Oil, and Grease at Mesophilic Conditions. Water Environment Research, 80(March 2008), 212-221. http://dx.doi.org/10.2175/106143007X220699

Kayhanian, M. (1999). Ammonia inhibition in high-solids biogasification: An overview and practical solutions. Environ Technol, 20(4), 355-365. http://dx.doi.org/10.1080/09593332008616828

Martín-Gonzáleza, L., Colturatoa, L. F., Fonta, X., \& Vicenta, T. (2010). Anaerobic co-digestion of the organic fraction of municipal solid waste with FOG waste from a sewage treatment plant: Recovering a wasted methane potential and enhancing the biogas yield. Waste Management, 30, 1854-1859. http://dx.doi.org/10.1016/j.wasman.2010.03.029

Wang, L. K., Hung, Y.-T., Lo, H. H., \& Yapijakis, C. (2006). Waste Treatment in the Food Processing Industry. CRS Press, Florida.

Long, J. H., Aziz, T. N., de los Reyes, F. L., \& Ducoste, J. J. (2012). Anaerobic co-digestion of fat, oil, and grease (FOG): A review of gas production and process limitations. Process Saf Environ, 90(3), 231-245. http://dx.doi.org/10.1016/j.psep.2011.10.001

McCarty, P. L. (1973). Methane Fermentation - Future Promise or Relic of the Past. Bioconversion Energy Reservation Conference.

Parker, W. J. (2005). Application of the ADM1 model to advanced anaerobic digestion. Bioresource technology, 96(16), 1832-1842. http://dx.doi.org/10.1016/j.biortech.2005.01.022

Polprasert, C. (1989). Organic waste recycling. John Wiley and Sons Inc.,New York, NY.

Sahm, C. C., Clerc, H. G., Schmidt, K. H., Reisdorf, W., Armbruster, P., Hessberger, F. P., Keller, J. G., Münzenberg, G., \& Vermeulen, D. (1985). Fusion probability of symmetric heavy, nuclear systems determined from evaporation-residue cross sections. Nuclear Physics A, 441(2), 316-343. http://dx.doi.org/10.1016/0375-9474(85)90036-3

Seghezzo, L., Zeeman, G., van Lier, J. B., Hamelers, H. V. M., \& Lettinga, G. (1998). A review: The anaerobic treatment of sewage in UASB and EGSB reactors. Bioresource Technol, 65(3), 175-190. http://dx.doi.org/10.1016/S0960-8524(98)00046-7

Shang, Y., Johnson, B. R., \& Sieger, R. (2005). Application of the IWA anaerobic digestion model (ADM1) for simulating full-scale anaerobic sewage sludge digestion. Water Sci Technol, 52(1-2), 487-492.

Silvestre, G., Rodriguez-Abalde, A., Fernandez, B., Flotats, X., \& Bonmati, A. (2011). Biomass adaptation over anaerobic co-digestion of sewage sludge and trapped grease waste. Bioresource technology, 102(13), 6830-6836. http://dx.doi.org/10.1016/j.biortech.2011.04.019

Tritt, W. P. (1992). The anaerobic treatment of slaughterhouse wastewater in fixed-bed reactors. Bioresource technology, 41(3), 201-207. http://dx.doi.org/10.1016/0960-8524(92)90002-F

Turovski1̌, I. S., \& Mathai, P. K. (2006). Wastewater sludge processing. Wiley-Interscience, Hoboken, N.J. http://dx.doi.org/10.1002/047179161x 
Wang, Y., Zhang, Y., Meng, L., Wang, J., \& Zhang, W. (2009). Hydrogen-methane production from swine manure: Effect of pretreatment and VFAs accumulation on gas yield. Biomass and Bioenergy, 33(9), 1131-1138. http://dx.doi.org/10.1016/j.biombioe.2009.04.004

Chen, Y., Cheng, J. J., \& Creamer, K. S. (2007). Inhibition of anaerobic digestion process: A review. Bioresource technology, 99(2008), 4044-4064.

Zhu, H., Parker, W., Basnar, R., Proracki, A., Falletta, P., Béland, M., \& Seto, P. (2008). Biohydrogen production by anaerobic co-digestion of municipal food waste and sewage sludges. International Journal of Hydrogen Energy, 33(14), 3651-3659. http://dx.doi.org/10.1016/j.ijhydene.2008.04.040

\section{Appendix A}

\section{Tables.}

Table 1. Municipal sludge (MS) and Bakery Wastes (BW) characteristics; data were collected from CWSID and CSM Bakery Products, Ogden, UT (2014)

\begin{tabular}{rrrr}
\hline Parameters & Unit & Municipal Sludge $^{\mathrm{a}}$ & Bakery Waste $^{\mathrm{b}}$ \\
\hline $\mathrm{pH}$ & & $7.15 \pm 0.09$ & $5.66 \pm 0.25$ \\
$\mathrm{TS}^{\mathrm{c}}$ & $\%$ & $4.87 \pm 0.34$ & $6.69 \pm 0.22$ \\
& & & $91 \pm 0.65$ \\
$\mathrm{VS}^{\mathrm{d}}$ & $\%$ of TS & $84 \pm 2.3$ & $93673 \pm 2109$ \\
$\mathrm{COD}^{\mathrm{e}}$ & $\mathrm{mg} / \mathrm{L}$ & $74492 \pm 2516$ & $51836 \pm 3230$ \\
$\mathrm{BOD}^{\mathrm{f}}$ & $\mathrm{mg} / \mathrm{L}$ & $31000 \pm 1200$ & $45 \pm 6.5$ \\
Alkalinity $\left(\mathrm{CaCO}_{3}\right)$ & $\mathrm{mg} / \mathrm{L}$ & $4113 \pm 229$ & BDL $^{\mathrm{h}}(<50 \mathrm{mg} / \mathrm{L})$ \\
$\mathrm{TKN}^{\mathrm{g}}$ & $\mathrm{mg} / \mathrm{L}$ & $1846 \pm 98$ & BDL $(<0.8 \mathrm{mg} / \mathrm{L})$
\end{tabular}

${ }^{a}$ Municipal sludge samples were collected from CWSID (June- October 2014)

${ }^{\mathrm{b}}$ Bakery Waste samples were collected from CSM Bakery Products (August- December 2014)

${ }^{\mathrm{c}}$ Total Solids; ${ }^{\mathrm{d}}$ Volatile Solids; ${ }^{\mathrm{e}}$ Chemical Oxygen Demand; ${ }^{\mathrm{f}}$ Biological Oxygen Demand; ${ }^{\mathrm{g}}$ Total Kjeldahl Nitrogen, ${ }^{\mathrm{h}}$ Below Detection Limit. 
Table 2. Default and modified values for the ADM1

\begin{tabular}{|c|c|c|}
\hline Kinetic parameters names & $\begin{array}{l}\text { Default values used in } \\
\text { the ADM } 1^{\text {a }}\end{array}$ & Modified Values ${ }^{b}$ \\
\hline Disintegration constant (K,dis) & $0.5\left(\mathrm{~d}^{-1}\right)$ & $0.5\left(\mathrm{~d}^{-1}\right)$ \\
\hline Hydrolysis constant of carbohydrates (Khyd, Ch) & $10\left(d^{-1}\right)$ & $13\left(d^{-1}\right)$ \\
\hline Hydrolysis constant of proteins (Khyd, Pr) & $10\left(d^{-1}\right)$ & $10\left(d^{-1}\right)$ \\
\hline Hydrolysis constant of lipids( Khyd, Li) & $10\left(d^{-1}\right)$ & $10.5\left(d^{-1}\right)$ \\
\hline Initial proteins concentration $(\mathrm{X}, \mathrm{Pr})$ & $15 \mathrm{~kg}\left(\mathrm{COD} \mathrm{m}^{-3}\right)$ & $15\left(\mathrm{Kg} \mathrm{COD} \mathrm{m}^{-3}\right)$ \\
\hline Initial lipids concentration $(\mathrm{X}, \mathrm{Li})$ & $20\left(\mathrm{~kg} \mathrm{COD} \mathrm{m}^{-3}\right)$ & $25\left(\mathrm{Kg} \mathrm{COD} \mathrm{m}^{-3}\right)$ \\
\hline Dynamic state variable for sugar $(\mathrm{xsu}, \mathrm{in})^{\mathrm{C}}$ & $0.00\left(\mathrm{Kg} \mathrm{COD} \mathrm{m}^{-3}\right)$ & $0.003\left(\mathrm{Kg} \mathrm{COD} \mathrm{m}^{-3}\right)$ \\
\hline Dynamic state variable for amino acid (xaa,in) & $0.01\left(\mathrm{Kg} \mathrm{COD} \mathrm{m}^{-3}\right)$ & $0.01\left(\mathrm{Kg} \mathrm{COD} \mathrm{m}^{-3}\right)$ \\
\hline Dynamic state variable for propionic acid (xpro,in) & $0.01\left(\mathrm{Kg} \mathrm{COD} \mathrm{m}^{-3}\right)$ & $0.03\left(\mathrm{Kg} \mathrm{COD} \mathrm{m}^{-3}\right)$ \\
\hline Sugar concentration $(\mathrm{Ssu})^{\mathrm{d}}$ & $0.1\left(\mathrm{Kg} \mathrm{COD} \mathrm{m}^{-3}\right)$ & $0.3\left(\mathrm{Kg} \mathrm{COD} \mathrm{m}^{-3}\right)$ \\
\hline Dynamic state variable for amino acid (Saa) & $0.001\left(\mathrm{Kg} \mathrm{COD} \mathrm{m} \mathrm{m}^{-3}\right)$ & $0.001\left(\mathrm{Kg} \mathrm{COD} \mathrm{m}^{-3}\right)$ \\
\hline Dynamic state variable for fatty acid (Sfa,in) & $0.001\left(\mathrm{Kg} \mathrm{COD} \mathrm{m}^{-3}\right)$ & $0.002\left(\mathrm{Kg} \mathrm{COD} \mathrm{m}^{-3}\right)$ \\
\hline Dynamic state variable for acetic acid (Sac,in) & $0.001\left(\mathrm{Kg} \mathrm{COD} \mathrm{m}^{-3}\right)$ & $0.002\left(\mathrm{Kg} \mathrm{COD} \mathrm{m}^{-3}\right)$ \\
\hline Dynamic state variable for propionic acid (Spro,in) & $0.001\left(\mathrm{Kg} \mathrm{COD} \mathrm{m} \mathrm{m}^{-3}\right)$ & $0.002\left(\mathrm{Kg} \mathrm{COD} \mathrm{m}^{-3}\right)$ \\
\hline Dynamic state variable for butyric acid (Sbu in) & $0.001\left(\mathrm{Kg} \mathrm{COD} \mathrm{m} \mathrm{m}^{-3}\right)$ & $0.002\left(\mathrm{Kg} \mathrm{COD} \mathrm{m}^{-3}\right)$ \\
\hline Dynamic state variable for valeric acid (Sva in) & $0.001\left(\mathrm{Kg} \mathrm{COD} \mathrm{m}^{-3}\right)$ & $0.002\left(\mathrm{Kg} \mathrm{COD} \mathrm{m}^{-3}\right)$ \\
\hline
\end{tabular}

${ }^{a}$ Values as recommended by (Batstone et al. 2002)

${ }^{\mathrm{b}}$ Modified values of the kinetics parameters. [XCh, XPr, and XLi] should be changed each time based on COD of MS:BW

${ }^{\mathrm{c}} \mathrm{X}=$ Particulate Component

${ }^{\mathrm{d}} \mathrm{S}=$ Soluble Component

Table 3. Statistical analysis results

\begin{tabular}{|c|c|c|c|c|c|c|c|c|c|}
\hline & \multicolumn{3}{|c|}{$10 \% \mathrm{BW}$} & \multicolumn{3}{|c|}{$20 \% \mathrm{BW}$} & \multicolumn{3}{|c|}{$30 \% \mathrm{BW}$} \\
\hline & Observed $^{\mathrm{a}}$ & Pred $^{b}$ & P-value ${ }^{c}$ & Observed $^{\mathrm{a}}$ & Pred $^{b}$ & $\mathrm{P}$ value & Observed $^{\mathrm{a}}$ & Pred $^{b}$ & $\mathrm{P}$ value \\
\hline $\mathrm{pH}$ & $7.22 \pm 0.073$ & 7.27 & 0.0505 & $7.03 \pm 0.07$ & 7.11 & 0.0711 & $7.13 \pm 0.09$ & 7.2 & 0.113 \\
\hline $\mathrm{VFA}^{\mathrm{d}}$ & $116 \pm 9.42$ & 95 & 0.00788 & $118 \pm 11$ & 114 & 0.57 & $118 \pm 11.7$ & 116 & 0.055 \\
\hline $\mathrm{Q}^{\mathrm{e}}$ & $0.6 \pm 0.02$ & 0.76 & 0.0098 & $0.72 \pm 0.04$ & 0.89 & 0.0083 & $0.80 \pm 0.031$ & 1.02 & 0.0047 \\
\hline $\mathrm{CH}_{4}{ }^{\mathrm{f}}$ & $0.466 \pm 0.11$ & 0.41 & 0.0046 & $0.5 \pm 0.01$ & 0.5 & 0.223 & $0.49 \pm 0.057$ & 0.57 & 0.003 \\
\hline
\end{tabular}

\section{Copyrights}

Copyright for this article is retained by the author(s), with first publication rights granted to the journal.

This is an open-access article distributed under the terms and conditions of the Creative Commons Attribution license (http://creativecommons.org/licenses/by/3.0/). 